\title{
Uncertainty Shocks and Asymmetric Dynamics in Korea: A Nonlinear Approach
}

\author{
Kevin Larcher*, Jaebeom Kim**, Youngju Kim**
}

The views expressed herein are those of the authors and do not necessarily reflect the official views of the Bank of Korea. When reporting or citing this paper, the authors' names should always be explicitly stated.

* Department of Economics, Oklahoma State University, E-mail: larcher@okstate.edu

** Department of Economics, Oklahoma State University, Tel: +1-405-744-7359, E-mail: jb.kim@okstate.edu *** Senior Economist, Macroeconomics Team, Economic Research Institute, The Bank of Korea, Tel: +82-2-759-5475, E-mail: econoky@bok.or.kr

The authors are grateful to Wook Sohn, Byung Kwun Ahn, Kook Ka, and an anonymous reviewer for their valuable comments and suggestions. 


\section{Contents}

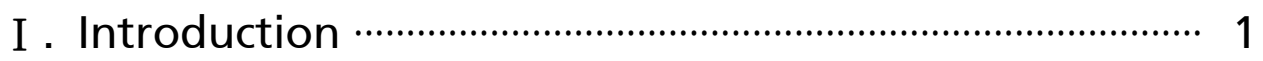

II . Data Description ………………………………………….... 5

III. Empirical Model ……………………………………............ 7

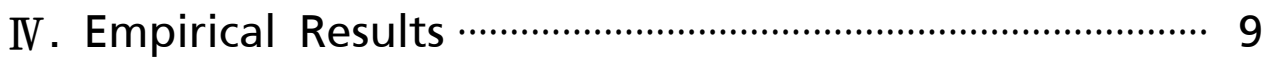

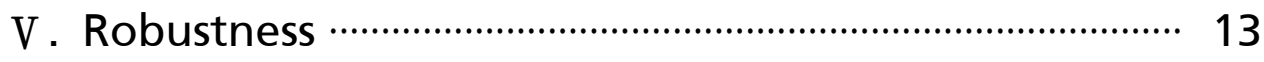

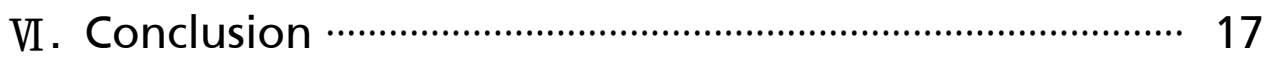

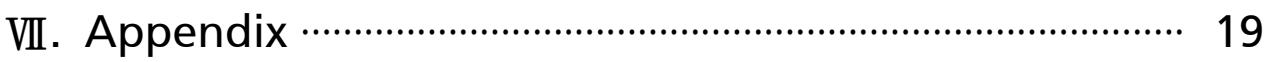

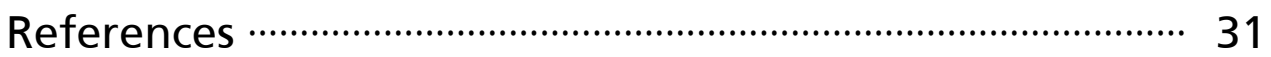




\section{Uncertainty Shocks and Asymmetric Dynamics in Korea: A Nonlinear Approach}

This study investigates the impact of uncertainty shocks on macroeconomic activity in Korea. For this purpose, a Smooth Transition VAR model is employed to document the state-dependent dynamics of two distinct types of uncertainty shocks, namely, financial market based and news-based. When nonlinearity is allowed to play a role in our model, quantitatively very different asymmetric dynamics are observed. Following in inflation targeting, the responses tend to be smoother and less pronounced. Our empirical results support the view that the link between uncertainty and macroeconomic activity is clear over both recessions and expansions. Furthermore, the impact of uncertainty shocks is more pronounced when economic activity is depressed especially after shocks originate from the financial market, and not from news-based policy uncertainty in Korea.

Keywords: Uncertainty shocks, Smooth transition vector autoregression, Asymmetric dynamics, Recessions

JEL Classification: C32, E32, E52 


\section{I . Introduction}

How do uncertainty shocks affect macroeconomic activity, and how does the process behave over the business cycle in Korea? Starting with the seminal work of Bloom (2009), there is a large body of literature which investigates the relationship between financial market uncertainty and the aggregate economy. Furthermore, Baker et al. (2016) construct an index of economic policy uncertainty $(E P U)$ and find that an unexpected increase in the same is associated with a significant and persistent drop in real activity in the response of the U.S. and a number of other countries. Regardless of the type of uncertainty shock, the recent consensus from a growing body of literature shows that uncertainty rises dramatically in recession. While this empirical evidence supports the common understanding of the link between uncertainty and macroeconomic variables, especially in an advanced economy, the question of whether the different proxies for uncertainty shocks affect macroeconomic variables in heterogeneous ways remains unanswered.

Even though a large body of theoretical literature focuses on the channels through which uncertainty has macroeconomic impacts on the domestic economy, ${ }^{1)}$ it is generally centered around the common effects of two different types of uncertainty shocks. The literature supports a general role for uncertainty in recessions, even though the uncertainty measures are strongly correlated with two different sources: financial and political uncertainty. While Bloom (2009), Arellano et al. (2012), Christiano et al. (2014), and Gilchrist et al. (2016) among others use financial market volatility as the proxy for the uncertainty shock, showing that uncertainty dampens the real economy through its influence on financial markets, a number of studies including Born and Pfeifer (2014),

1) See Bloom (2009), Bloom et al. (2012) for real option effects; Van Nieuwerburgh and Veldkamp (2006), Fajgelbaum et al. (2014) for feedback (uncertainty trap) channel; Fernandez-Villaverde et al. (2011) for precautionary savings channel; Carriere-Swallow and Céspedes (2013) for credit channel; Gertler et al. (2007) for financial friction for small open economy; Basu and Bundick (2012) and Leduc and Liu (2012) for search frictions channel. 
Fernandez Villaverde et al. (2015), and Baker et al. (2016) find that policy risk or news-based shocks are also significant in understanding how uncertainty impacts the macroeconomic environment. Recently, Ng and Wright (2013) show that all post-1982 recessions have their roots in financial markets, and these recessions have considerably different features from recessions where financial markets play a passive role. Moreover, Ludvigson et al. (2015) argue that higher uncertainty in recessions is more likely to be an endogenous response to business cycle fluctuations, while the financial market uncertainty seems to be a source of these fluctuations. Based on this perspective, as well as the recent observation of the divergence between policy uncertainty and stock market volatility in Korea, if uncertainty shocks are still an important source of business cycle fluctuations, and financial markets play a key role in an economy, two popular measures of uncertainty shocks might affect the macroeconomic variables in different ways.2)

Linear Vector Autoregression (VAR) models are standard in many empirical macroeconomic studies including Bloom (2009), however, as shown by Koop and Potter (1999), van Dijk et al. (2002), and Morley et al. (2012), macroeconomic variables have been shown to have asymmetric dynamics over different phases of the business cycle. Moreover, the recent financial crisis highlights the fact that economic downturns can be far sharper than recoveries and uncertainty usually peaks in deep recessions. The stylized facts along with the recent observations easily lead us to consider a non-linear framework. Considering this, recessionary events seem to be informative periods for the identification of the asymmetric effects of uncertainty shocks in the aggregate economy.

This study examines the effects of two distinct types of uncertainty shocks on the aggregate economy of Korea.3) The main research questions

2) The recent observation of the divergence between policy uncertainty and stock market volatity in Korea is likely to suggest that two popular measures of uncertainty shocks might affect the macroeconomic variables in different fashions. (i.e., The highest $E P U$ index but the lowest $K V O X$ index in 2016 due to the Presidential Scandal and the impeachemnt of President Park by the parlianment in late 2016.)

3) Choi and Sim (2016) compared the impacts of financial uncertainty and policy uncertainty on business cycles in Korea with a linear VAR. Shin et al. (2018) construct Korean macroeconomic uncertainty measure and find that their measure explains aggregate fluctuations well in Korea. 
are: How does uncertainty-and two different types of uncertainty-affect macroeconomic variables in Korea? Is this process asymmetric over the business cycle? The issue addressed in this study is the extent to which the responses of macroeconomic variables vary with two different uncertainty shocks in the pre- and post-Asian Financial Crisis (1997-1998), which coincided with the adoption of inflation targeting in 1998 in Korea. To answer these questions, a Smooth Transition VAR (STVAR) by Granger and Teräsvirta (1993) is employed to analyze the possible nonlinear effect of uncertainty on macroeconomic variables in Korea. Two distinct measures for uncertainty are considered: A measure of financial uncertainty from the KOSPI (Korean composite stock market index), and a measure of economic policy uncertainty index.

Comparisons are made, together with financial uncertainty and EPU index, and headline and core inflation, between recession and expansion as well as linear $V A R$ and nonlinear STVAR models. Furthermore, since we observe the structural break in the data due to the Asian Financial Crisis of 1997-1998, which coincides with the switch to inflation targeting monetary policy regime in 1998, we also estimate the post inflation targeting periods from 1998. Our empirical findings are interesting, and they are as follows: First, we find evidence that there are significant asymmetric responses of inflation and unemployment in a recession, vs. an expansion similar to the findings in Caggiano et al. (2017), and Caggiano et al. (2014). The findings from non-linear $S T V A R$ which allows us to separate the impact of uncertainty shocks for recessions provide clear evidence for asymmetric dynamics for macroeconomic variables. The asymmetric empirical evidence implies that linear $V A R$ models which are generally mixing up different phases of the business cycles might lessen the effects driven by uncertainty shocks, suggesting that the effects of uncertainty shocks from the non-linear STVAR analysis featuring two different phases may be larger than what a linear model would suggest.

Second, the type of uncertainty shocks matters, and the degree of asymmetry in the responses depends on where the shock originated. 
Financial market volatility shocks have a greater impact on macroeconomic variables than EPU shocks. Similarly, forecast error variance decomposition shows that financial market volatility explains a great deal of the macroeconomic variances, implying that news-based uncertainty might not be a major source of business cycle fluctuations in Korea. While economic policy uncertainty mainly concerns uncertainty about domestic political and economic events and actions, financial market in Korea is directly linked to the global financial markets and international economic fluctuations driven by large open economies. This finding is in line with Ludvigson et al. (2015) in that financial market based uncertainty is a major source of business cycle fluctuations in Korea, where financial markets play a key role and which adapted an export oriented industrial strategy to spur its economic growth. Moreover, our observation in this study is also consistent with the findings in Caldara et al. (2016), Christiano et al. (2014), Gilchrist et al. (2014), and Arellano et al. (2010), indicating that a possible amplification mechanism and source of persistence for the uncertainty shock might be the financial friction channel in an emerging economy such as Korea. Furthermore, the empirical evidence from a nonlinear $V A R$ is more obvious than the one predicted by a linear $V A R$, and is also robust to a variety of orderings of our baseline vector with different variables, sub-sample analysis, and different specifications.

These empirical findings viewed together are in support of the assessment that high uncertainty accompanies deep recessions. When nonlinearity is allowed to play a role in our model, quantitatively quite different asymmetric dynamics are observed. Moreover, although the asymmetric dynamics are apparent over both business cycle regimes, the impact of uncertainty is more pronounced when economic activity is depressed, especially after shocks originate from the financial markets and not from news-driven policy uncertainty in Korea. 


\section{Data Description}

To model responses of key macroeconomic variables to uncertainty shocks, we follow Caggiano et al. (2014) and consider a set of macroeconomic variables from four sources: DataStream, Korean Exchange, www.policyuncertainty.com and the St. Louis Fed FRED database. They are uncertainty, inflation, unemployment, and the policy rate measured by overnight loan rate which is the proxy for monetary policy. Inflation is based on the percentage change of the consumer price index $(C P I)$. Headline inflation is used in our baseline model, but for a robustness check, we estimate the model with core inflation without volatile components such as food and energy. The data are monthly and cover the period of January 1991 to December 2016.4) The summary statistics and sources of the variables are presented in Table 1. Interestingly, the correlation between EPU and financial market uncertainty index is only 0.05 and the mean values of the two different indexes in two distinct regimes are quit different, implying a possibly heterogeneous role of two distinct types of uncertainty shocks on the aggregate economy of Korea.

Two different proxies for uncertainty are employed; a measure of financial uncertainty from the KOSPI and the EPU index. For the measure of financial uncertainty from the $K O S P I$, we follow Bloom (2009), and use the implicit volatility of KOSPI (VKOSPIX), which is the best alternative for the VIX (Chicago Board Options Exchange Volatility Index) in Korea. This index measures stock market volatility one month ahead and captures forward-looking information. However, since VKOSPIX is only available from 2003, we compute the realized volatility from 1991 to 2002 based on the monthly standard deviation of the daily

4) The beginning of the sample of 1991 is due to data on several key variables being unavailable prior and the lack of suitable proxy for those variables. Monthly variables are employed for a couple of reasons. A lower frequency data usually smoothes out much of the variation and fluctuations of the variables concerned. Further, a higher frequency observation alleviates any issues related to zero contemporaneous restrictions employed for structural modeling. 
return of the KOSPI matched to the same mean and standard deviation of the VKOSPIX from 2003 onward, and combine them to produce a consistent measure of financial uncertainty for Korea.5)

For economic policy uncertainty, we employ the $E P U$ index for Korea by Baker et al. (2016).6) They calculate the number of news articles that considers the following terms relative to the entire news articles in questions: Uncertain or uncertainty; economic, economy or commerce. They also use one or more of the following policy relevant terms: Government, Blue House, congress, authorities, legislation, tax, regulation, the Bank of Korea, central bank, deficit, WTO, law/bill, and ministry of finance. After they standardize each paper's EPU to unit standard deviation from 1995 to 2014, they average it across the papers by month, and then rescale the resulting series to a mean of one hundred from January 1990 to December 2014.

Figure 1 plots the volatility series and recessionary periods for Korea based on OECD recession indicators during the sample period. It is easily observed that recessions are associated with heightened uncertainty in the financial market, and with the $E P U$ index. These include historical political and economic events such as the enactment of the Real Name Financial Transactions in August 1993, the death of Kim Il-Sung in July 1994, and Asian Financial Crisis in August 1997, which can be considered as uncertainty shocks in the 1990s. Other notable political and economic events in the heightened EPU index in the 2000s are the bankruptcy of Daewoo Motors in November 2000, Gulf War II in 2003, the Global Financial Crisis in 2008, and the Presidential Scandal and the impeachment of President Park by the parliament in late 2016. These can obviously be seen as considerable shocks which cast uncertainty in Korean aggregate economy.

5) The VKOSPIX from the datastream is available only after April, 2009. We empolyed both and no difference is found between them.

6) The EPU index is the only available standardized policy uncertainty index. To construct the $E P U$ index for Korea, six news papers are used: Donga-Ilbo, Kyunghyang Shinmun, Maeil Business Newspaper, Hankyore Shinmun, Hankook Ilbo, and the Korea Economic Daily. 


\section{Empirical Model}

Following Auerbach and Gorodnichenko (2012) and Caggiano et al. (2014), we make use of $S T V A R$ to analyze the possible non-linear effects of uncertainty on dynamics of macroeconomic variables. According to Granger and Teräsvirta (1993), the $S T V A R$ framework employs a regime switching $V A R$ in which the transitions between recession and expansion are smooth.7) This modeling strategy allows us to take advantage of the degree to which the economy is in expansion or recession and also allows for the segregation of different regimes. More specifically, it exploits variation in the degree (or probability) of being in a recession or an expansion. The STVAR takes the following form:

$$
X_{t}=F\left(z_{t-1}\right) \Pi_{R}(L) X_{t-1}+\left(1-F\left(z_{t-1}\right)\right) \Pi_{N R}(L) X_{t-1}+\mu_{t}, \mu_{t} \sim N\left(0, \Omega_{t}\right)
$$

$X_{t}$ is an $N \times 1$ set of macroeconomic variables entering the data set. $F\left(z_{t}\right)$ is a function bounded between zero and one. The state-dependent variance-covariance matrices $\Omega_{R}$ and $\Omega_{N R}$ act as the contemporaneous propagation of structural shocks and the lag polynomials $\Pi_{R}(L)$ and $\Pi_{N R}(L)$ act as the dynamic propagation of the structural shocks in recessions $(R)$ and expansions $(N R)$. The variance covariance matrices of the reduced form residual $\Omega_{t}$ is defined as follows:

$$
\Omega_{t}=F\left(z_{t-1}\right) \Omega_{R}+\left(1-F\left(z_{t-1}\right)\right) \Omega_{N R}
$$

The variable $z_{t}$ is a normalized index of the business cycle, where positive values indicate an expansion and negative indicate a recession. $F\left(z_{t-1}\right)$ is a logistic transition function which captures the probability of being in a recessionary or expansionary phase. We define the transition

7) For more details, see Granger and Teräsvirta (1993). 
function as follows:

$$
F\left(z_{t}\right)=\frac{\exp \left(-\gamma z_{t}\right)}{\left(1+\exp \left(-\gamma z_{t}\right)\right.}, \gamma>0, z_{t} \sim N(0,1)
$$

Setting the smoothness parameter to $\gamma>0$ and letting the index $z_{t}$ be the transition indicator, one can then interpret $\Omega_{R}$ and $\Pi_{R}(L)$ as describing the system when it is in a recession $\left(F\left(z_{t-1} \approx 1\right)\right)$ and $\Omega_{N R}$ and $\Pi_{N R}(L)$ as describing the system when it is in an expansion $\left(1-F\left(z_{t-1} \approx 1\right)\right)$. We use the 12 month moving average of the growth rate of industrial production as our transition indicator variable, a common adoption in the literature. The model therefore can be described as a combination of two VARs in which transitions between 'two states'(i.e. recession and expansion) are smooth and regulated by the transition indicator $\gamma$. Conditional on negative values of the transitions indicator $z_{t}$, the transition function indicates the probability of being in a recessionary stage. When the probability of being in a recession is sufficiently high, the model switches to capturing the effects of the shock in a recession.8) This transition is regulated by the calibration of $\gamma$. High calibrations for $\gamma$ imply abrupt regime switches, and the assumption that the economy is spending less time in the recessionary phase. Vice versa for lower calibrations. If $\gamma=0$ the mode becomes linear and in the case of $\gamma$ calibrated to infinity, the model would become discrete. In the case of Korea, more time was spent in recession following 1998. We calibrate $\gamma=1.5$ for the period 1998M4-2016M12 $\left(F\left(z_{t}\right) .75\right)$ and $\gamma=1.75\left(F\left(z_{t}\right) .8\right)$ for period 1991M4-2016M12.9) The transition function $F\left(z_{t}\right)$ shown in

8) We set the threshold for the probability as indicated by the transition function at .8 in this paper following Auerbach and Gordnichenko (2012) and Caggiano et al. (2014).

9) We calibrate it again for the sub-sample because for the full sample period, Korea experienced longer periods of recession. As robustness we estimated a range of $\gamma$ calibrations from $\gamma=1.25$ and $\gamma=2$. The results were robust to these calibrations. 
Figure 2 tend to follow the OECD recessionary periods for Korea.

Our baseline analysis is contingent on the vector

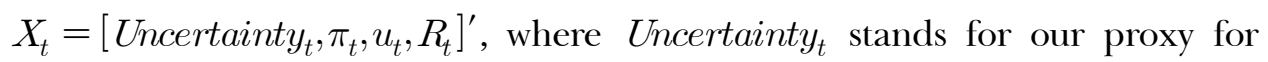
uncertainty, either $E P U_{t}$ or $V K O S P I X_{t}, \pi_{t}$ stands for inflation, $u_{t}$ is the unemployment rate, $R_{t}$ is a policy rate.10) Following Caggiano et al. (2014), the identification of exogenous variations of the uncertainty index will be achieved via the widely adopted Cholesky assumption, which implies that on-impact macroeconomic effects by the identified uncertainty shocks are allowed.11) Based on Auerbach and Gorod-nichenko (2012) and Caggiano et al. (2014) the models including both linear $(\gamma=0)$ and nonlinear $(\gamma>0)$ formulations are estimated via Monte-Carlo Markov-Chain simulation proposed by Chernozhukov and Hong (2003). Following Koop et al. (1996), effects of the uncertainty shock are computed by assuming that they start in a recession and remain in the state.12) As discussed in Caggiano et al. (2014), this is desirable as the impulse response will not depend on initial conditions nor on the size of the shock and thus are not simply functions of history. Generalized impulse response functions (GIRFs) are computed as in Koop et al. (1996) and reported as the median response of the $95 \%$ confidence band.

\section{Empirical Results}

Two sample periods are considered in our baseline approach, the full sample, covering 1991M1-2016M12, and the sub-sample for 1998M42016M12, due to the structural break in terms of both the Asian Financial Crisis of 1997-1998, and the switch to inflation targeting monetary policy regime in 1998.13)

10) Following Teräsvirta (1994) and Teräsvirta and Yang (2014), several tests are conducted to test for linearity as well as to confirm correct specification of transition function. See Appendix for details.

11) No recursive ordering is right because we are using monthly data. See footnote 4 for details.

12) For technical details, see Auerbach and Gorodninchenko (2012) and Chernozhukov and Hong (2003). 


\section{Full Sample Results for 1991-2016}

Figure 3 plots estimated impulse responses to a one standard deviation shock of VKOSPIX and EPU respectively contingent on a recession and expansion. Starting with the recession contingent responses, on impact, headline inflation decreases by about $.02 \%$ and the decrease stays significant for about 30 months. The EPU shock has a small negative impact on inflation in the sample period and the decreases are slight and hardly significant. The unemployment rate increases much more in a recession from a VKOSPIX shock than an EPU shock (roughly 10 times smaller than from the VKOSPIX shock). Unemployment increases by $.02 \%$ and $.002 \%$ respectively from a VKOSPIX and EPU shock. In terms of the policy rate, the estimates show a somewhat opposite path when the pre-inflation targeting era is included. On impact, the VKOSPIX shock raises the policy rate in a recession for about 10 months, before going back to zero. ${ }^{14)}$ The recession contingent shock to the EPU shows no discernible impact on policy rate.

An interesting and slightly different relationship is estimated via the expansion contingent $V A R$. Following a $V K O S P I X$ or $E P U$ shock in an expansion, headline inflation is shown to increase, contrary to the recession contingent estimates. The VKOSPIX impact is roughly 5 times as large as the EPU impact at $.025 \%$ and $.005 \%$ respectively. Unemployment follows a similar pattern to the previous estimates, but are less pronounced, which may be expected since a common theme in the literature is that macro variables tend to be less sensitive to shocks in an expansion than in a recession. In an expansion, the policy rate is much more responsive to the $E P U$ news-based shock when the full sample period is considered in the model.

13) We also estimated the pre-crisis period (1991-1997). Unfortunately, however, the sample period is too short to reach a convergence for STVAR.

14) In a world with perfect captial mobility, when uncertainty rises, it is not surprising that the central banks raise the rate to avoid any captial outflows. See Rey (2016) for details. 
While the responses on recessions are quantitatively quite different, a similar pattern emerges in responses when uncertainty shocks are estimated in a linear $V A R$. Though the responses to the news-based $E P U$ shock show a very similar pattern to the $V K O S P I X$ shock, they are quantitatively much smaller than those of the VKOSPIX shock. Inflation, however, decreases on impact, instead of with a lag. Simultaneously, unemployment rises, and the policy rate falls. The interesting point observed is that the shock is nearly ten times greater in some instances comparing the VKOSPIX shock to the EPU shock. Overall, the empirical finding is somewhat contrasting to Baker et al. (2016) and Caggiano et al. (2017), who find substantial impacts of policy uncertainty shocks on the U.S. economy. However, it supports Born and Pfeifer (2014), who provide evidence showing insignificant effects of policy uncertainty on the U.S. macroeconomic activity. Most importantly, although the empirical evidence from STVAR seems to show similar dynamics compared to a linear $V A R$, when nonlinearity is introduced in our model, quantitatively and statistically quite different dynamics are observed.

\section{Sub-sample Results for $1998-2016$}

There exists the structural break in the data due to the Asian Financial Crisis of 1997-1998, which coincides with the switch to inflation targeting monetary policy regime in 1998. In order to avoid any issues related to biased estimation, we also estimate the post inflation targeting periods from 1998M4.15) An interesting question, yet to be addressed specifically, for the sub-sample analysis, is whether inflation targeting lowers inflation uncertainty and unemployment uncertainty due to central bank transparency and commitment to policy directives after the Asian Financial Crisis. The

15) We considered three cases from 1998:1, 1998:4, and 1999:1, and then reported the case with 1998:4 simply because the BOK initiated inflation targeting at the second quater of 1998 . There is no difference in terms of empirical results between the three cases. 
nonlinear $V A R$ system will also allow us to explore the relationship and the hypothesis further, by investigating whether inflation targeting is an important factor in stabilizing the aggregate economy after uncertainty shocks and whether the relationship changes when accounting for the business cycle.

Figure 4 plots dynamic behavior over the sample period of 1998-2016 from the nonlinear $V A R$ system contingent on a recession and an expansion. On impact, headline inflation decreases following the $V K O S P I X$ and $E P U$ shocks. Again, the result being nearly five times as strong for the VKOSPIX shock, compared to the EPU shock. Unemployment rises significantly following a VKOSPIX shock, with no discernible impact in the $E P U$ shock. The policy rate decreases by about one basis point after a VKOSPIX shock only, following a pattern consistent with an inflation targeting strategy by the Bank of Korea.16) This is in line with Basu and Bundick (2012) and Leduc and Liu (2013), implying that uncertainty shocks, especially the VKOSPIX shocks, act as aggregate demand shocks.

The estimates contingent on an expansion are less pronounced. Both the $V K O S P I X$ and EPU shocks produce minor changes in headline inflation. Unemployment reacts slightly negatively due to a VKOSPIX shock and insignificantly due to an $E P U$ shock. The policy rate is hardly changed due to a VKOSPIX shock, but does decrease in response to an $E P U$ shock in an expansion. Overall the expansion contingent estimates indicate that uncertainty shocks are not a huge driver of the adjustment of the variables in the system in an expansion.

As can be seen from the full sample, a similar dynamic behavior is observed in a linear $V A R$, although the responses are quantitatively different in a nonlinear $V A R$. Headline inflation shows a similar pattern, yet is entirely unaffected by the $E P U$ shock. Unemployment increases, yet

16) Inflation targeting is important as one of factors to stabilize the economy after uncertainty shocks, not the most important factor. 
the increase is slightly less than in the longer sample period. The policy rate drops by around one basis point following VKOSPIX shock and by slightly less than one basis point in response to an EPU shock. In summary, the empirical finding from the sub-sample analysis shows that inflation targeting seems to play a significant role in lowering inflation and unemployment uncertainties. In particular, the evidence from a nonlinear $V A R$ shows that financial uncertainty shocks are more dominant than the policy uncertainty shocks.

\section{Forecast Error Variance Decomposition}

To assess the contribution of two different types of uncertainty shocks for the dynamics of macroeconomic variables concerned, we perform a forecast error variance decomposition $(F E V D)$. Table 2 documents the 24-month- ahead FEVD for the VKOSPIX and EPU shocks. Depending on recessions for both sample periods, EPU shocks explain only around $1 \%$, and are negligible for inflation, unemployment rate, and policy rate. Conversely, dependent on recessions for both sample periods, a $V K O S P I X$ shock explains significant amounts of the variances in the variables concerned. The same is true for the contributions of both of the uncertainty shocks dependent on expansions. This confirms our main finding that the VKOSPIX has a greater influence on macro variables than the news-based index.

\section{Robustness}

First, we use the core inflation rate to examine possible changes compared with headline inflation. Second, we include both the EPU and VKOSPIX in the same VAR system, to account for possible interdependence between the two. Third, several other omitted variables to be included in our VAR system are suggested by the literature, such 
as industrial production, the log level of the stock market index, and the exchange rate.17) Finally, we also conduct sensitivity tests with respect to the $V A R$ system ordering, lag selection, and calibration of the smoothness parameter. Overall our results were confirmed by the robustness test.

\section{Core Inflation}

To test whether headline inflation is an appropriate target, and how our results may change under inflation targeting, core inflation is also considered in our model. This is partly due to the fact that monetary policy should not be held responsible for non-monetary factors that influence prices. ${ }^{18}$ ) Based on the impulse responses in Figures 5 and 6 , we did not find a significant difference, but did find similar behaviors between the variables. A shock to either uncertainty index causesaddress a decrease in inflation, an increase in unemployment, and a decrease in the policy rate. The effects are once more significantly larger when the shock is due to the VKOSPIX. The effects are around 5 times larger for the three variables of inflation, unemployment, and the policy rate. This confirms the overall conclusion that financial market volatility plays a significantly greater role in influencing macro variables under inflation targeting than news-based shocks.

\section{The EPU and VKOSPIX Index}

As done by Bacchetta and Van Wincoop (2013), to test whether uncertainty regarding global financial markets is more dominant than political uncertainty, and to document the differences and similarities of the type of shock affecting the aggregate economy, we include both the $E P U$ and VKOSPIX in the same VAR system. Even though the two

17) For details, see Caggiano et al. (2014).

18) See Hoffmaister (2001) and Bodenstein et al. (2008) for details. 
indices are based on separate underlying indicators, there might be some level of interdependence and an interrelationship between the two different types of uncertainty. The findings from the impulse response functions in Figure 7 indicate that one standard deviation shock to the VKOSPIX index raises the $E P U$ index for the recession by sizable amounts, while an $E P U$ shock has a negligible impact on the VKOSPIX. Although two different uncertainty shocks are important in the U.S., it is likely that uncertainty regarding financial market, rather than domestic economic policy uncertainty, plays a more dominant role in explaining business cycle fluctuations in an emerging economy such as Korea.

\section{Omitted Variables and Specification}

To avoid any issues related to model misspecification, we consider three omitted variables in our VAR system: KOSPI stock market index, industrial production, nominal effective exchange rate $(N E E R)$.

\subsection{The KOSPI Index}

Following Caggiano et. al (2014), we add the KOSPI stock market index to the $V A R$ system so that our vectors of variables becomes $X_{t}=\left[V K O S P I X_{t}, \pi_{t}, \mu_{t}, \operatorname{KOSPI}_{t}, r_{t}\right]^{\prime}$ and $X_{t}=\left[V K O S P I X_{t}, E P U_{t}, \pi_{t}, \mu_{t}, \operatorname{VOSPI}_{t}\right.$ ,$\left.r_{t}\right]^{\prime}$. Though VKOSPIX captures the volatility of the KOSPI, variations in the log level of the KOSPI itself may be an important determinant of fluctuation in our time series. Figure 8 captures the impulse responses of $V K O S P I X$ and $E P U$ shocks to inflation, unemployment and the policy rate when the KOSPI is placed in the VAR system. These robustness checks were carried out on the sample period following inflation targeting. A negligible impact is observed, and the baseline model results are robust to the inclusion of the variables. 


\subsection{Industrial Production}

To the extend that monetary policy is based solely on the relationships between unemployment and inflation is a strong assumption. To see any sensitivity issues related to the absence of changes in aggregate demand in terms of nonlinear dynamics, we place the $\log$ level of industrial production in our $V A R$ system. Based on Figure 8, the addition of industrial production does not substantially change our results from the baseline estimates.

\subsection{NEER}

To account for a small open economy issue, and to test the extent to which the addition of the exchange rate may influence our model, we include the nominal effective exchange rate $(N E E R)$. Figure 8 plots impulse responses and the same dynamics captured in our baseline specification are in fact robust to the inclusion of the exchange rate.

\subsection{Alternative Model Specifications}

Alternative model specifications are considered with reverse orderings of the variables in the system, different lag lengths, and different calibration of $\gamma$. First we run variations on the orderings. As discussed by Caggiano et al. (2014) this allows us to purge uncertainty variables, which allows for both contemporaneous and lagged shocks in the system to affect the uncertainty variables. Second, we adjust lag lengths of the main regression in the model as well. ${ }^{19)}$ Finally, following Auerbach and Gorondnicheko (2012) and Caggiano et al. (2014), different calibration of is considered to see how the dynamic responses may differ and to match the OECD recession dates for Korea. The results in Figures 9 and 10

19) We use five for the full sample and four for subsample based on AIC and BIC. The models were also run with higher and lower lag lengths. 
confirm the negligible impact of uncertainty shocks on aggregate economic activity in Korea. Further, the nonlinearity in the system and asymmetric dynamics in recession and expansion are still present after changing the specifications in our model.

\section{Conclusion}

How do two different types of uncertainty affect macroeconomic variables, and how does the process perform over the business cycle in Korea? The issue addressed in this study is the extent to which the responses of macroeconomic variables vary with two different uncertainty shocks in pre- and post-Asian Financial Crisis (1997-1998), which coincides with the adoption of inflation targeting in 1998 in Korea. To answer these questions, a nonlinear $S T V A R$ as well as two distinct measures for uncertainty are considered. Our findings are interesting, and they are as follows: First, we find significant asymmetric responses of inflation and unemployment in recession vs. expansion. The asymmetric empirical evidence from STVAR for unemployment and other aggregate variables over different phases of the business cycles implies that linear models baffling recessions and expansion phases might minimize the effects driven by uncertainty shocks. Second, the type of uncertainty shocks matters, and the degree of asymmetry in the responses depends on where the shock is from. When the full sample period is considered, financial market volatility shocks have greater impact on macroeconomic variables than $E P U$ shocks. Following inflation targeting, the responses tend to be smoother and less pronounced. Forecast error variance decomposition supports our empirical findings, and shows that financial market volatility has significantly more explaining power over the variables considered. This empirical finding is somewhat in contrast with Baker et al. (2016) and Caggiano et al. (2017), who find significant impacts of $E P U$ shocks on the U.S. economy. However, it is consistent with Born and Pfeifer (2014), who show no significant impact of policy risk shock 
on the aggregate variables. Following Ludvigson et al. (2015), it seems that news-based uncertainty which is not likely to be a comprehensive measure of uncertainty is not a major source of business cycle fluctuations, while uncertainty from financial markets is a major source, especially in an emerging economy such as Korea, whose financial market is highly integrated with the world financial markets, and which adapted an export-oriented industrial strategy to spur its economic growth. Consistent with the findings in Caldara et al. (2016), Christiano et al. (2014), Gilchrist et al. (2014), and Arellano et al. (2010), the obervation in this study indicates that a possible amplification mechanism and source of persistence for the uncertainty shock might be the financial friction channel in Korea.

Viewed as a whole, our empirical results support the view that recessions are usually associated with high uncertainty, while uncertainty originating from financial markets might be a key player in the fluctuations. Although the empirical evidence from $S T V A R$ shows similar dynamics comparing to a linear $V A R$, when nonlinearity is allowed to play an important role in our model, quantitatively very different asymmetric dynamics are observed. Moreover, while the asymmetric dynamics are apparent over both business cycle regimes-expansion and recession- the impact of an uncertainty shock is more pronounced when economic activity is depressed, especially after shocks originating from the financial market, not from news-driven policy uncertainty in Korea. 


\section{Appendix}

Following Teräsvirta (1994) and Teräsvirta and Yang (2014), several tests are conducted to test for linearity as well as to confirm correct specification of transition function. The first test allows for the testing of nonlinearity between the exogenous variable and the choice of transition variable. Secondly, it allows to test between the correct choice of transition function: exponential or logarithmic. Consider the general form of the $S T A R$ model:

$$
y_{t}=\delta_{0}+\delta_{1}^{\prime} x_{t}+\beta_{1}^{\prime} x_{t} z_{t-d}+\beta_{2}^{\prime} x_{t} z_{t-d}^{2}+\beta_{3}^{\prime} x_{t} z_{t-d}^{3}+\mu_{t}
$$

where $y_{t}$ is a scalar, $x_{t}=\left(1, y_{t-1}, y_{t-2}, \ldots, y_{t-p}\right)^{\prime}$ and $z_{t-d}$ is an exogenous variable. In this case $y_{t}$ is inflation rate and $z_{t}$ is the choice of switching variable, industrial production index for Korea. Under the null hypothesis of linearity: $H_{0}: \beta_{1}=\beta_{2}=\beta_{3}=0$. The $L M$ test based on the above type of model is performed as follows:

1. To test for linearity, estimate (A1) under the hull hypothesis (restricted model of federal funds rate on its own lags). Collect the residuals $\left(S S R_{0}\right)$. Regress residuals on the regressors for $(\mathrm{Al})$ and collect residuals $\left(S S R_{1}\right)$. The $L M$ test now becomes $\left.T\left(S S R_{0}-S S R_{1}\right) / S S R_{0}\right)$ which is distributed $x^{2}$ in large samples, however in small samples it is more appropriate to use $F$-test. The test rejects linearity with a $p$-value of .001 . Confirming a high degree of non linearity in the relationship.

2. Under the null hypothesis of $H_{0}: \beta_{3}=0$ we would reject the use of exponential transition function in favor of logarithmic. The test rejects the null with p-value of .0387. Confirming the use of logarithmic function is well suited for the analysis. In order to 
confirm nonlinear dynamics at the multivariate level we run the test proposed by Teräsvirta and Yang (2014). The test is similar to the previous, however, augmented to conform to the vector-STAR model. Consider the $L S T V A R$ model:

$$
Y_{t}=\theta_{0}^{\prime} X_{t}+\theta^{\prime}{ }_{1} X_{t} z_{t}+\epsilon_{t}
$$

where $\quad X_{t}=\left[E P U_{t}, \pi_{t}, \mu_{t}, r_{t}\right]^{\prime}, X_{t}=\left[\operatorname{VKOSPIX}, \pi_{t}, \mu_{t}, r_{t}\right]^{\prime}$ are the $(p \times 1)$ vectors of endogenous variables, $X_{t}=\left[\left|Y_{t-1}\right| \ldots\left|Y_{t-1}\right| \alpha\right]^{\prime}$ is the $(k \times p+q))$ vector of exogenous variables, $z_{t}$ is the choice of transition variables (industrial production) and $\theta_{0}$ and $\theta_{1}$ are matrices of parameters. In this case number of endogenous variables $p=4$, the number of lags $k=1$ (via Teräsvirta and Yang (2012)) and the number of exogenous variables $q=1$. Under the null hypothesis of linearity $\theta_{1}=0$. The test is performed as follows:

3. Estimate the restricted model $\left(\theta_{1}=0\right)$ by regressing $Y_{t}$ on $X_{t}$ and collect sum of square residuals $S S R_{0}=E^{\prime} E$.

4. Regress $E$ on the unrestricted model (5) and collect residual sum of squares $S S R_{1}=\Psi^{\prime} \Psi 4$

5. Compute test statistic $L M=T \times \operatorname{trace}\left(S S R_{0}-S S R_{1} / S S R_{0}\right)$ which is distributed $x^{2}$ with $(p(k p=q)$ degrees of freedom. In this case the degrees of freedom were 20 and the computed $L M$ statistic was 106.7175 and 61.8564 respectively for models with the VKOSPIX or EPU shocks. The resulting p-values respectively are .0001 and .00001 , in which case the null of linearity is rejected. In sum, the tests confirm that linearity is rejected at the single and multivariate level and confirm that a logistic transition function is appropriate. 
Figure 1. Volatility of KOSPI and EPU

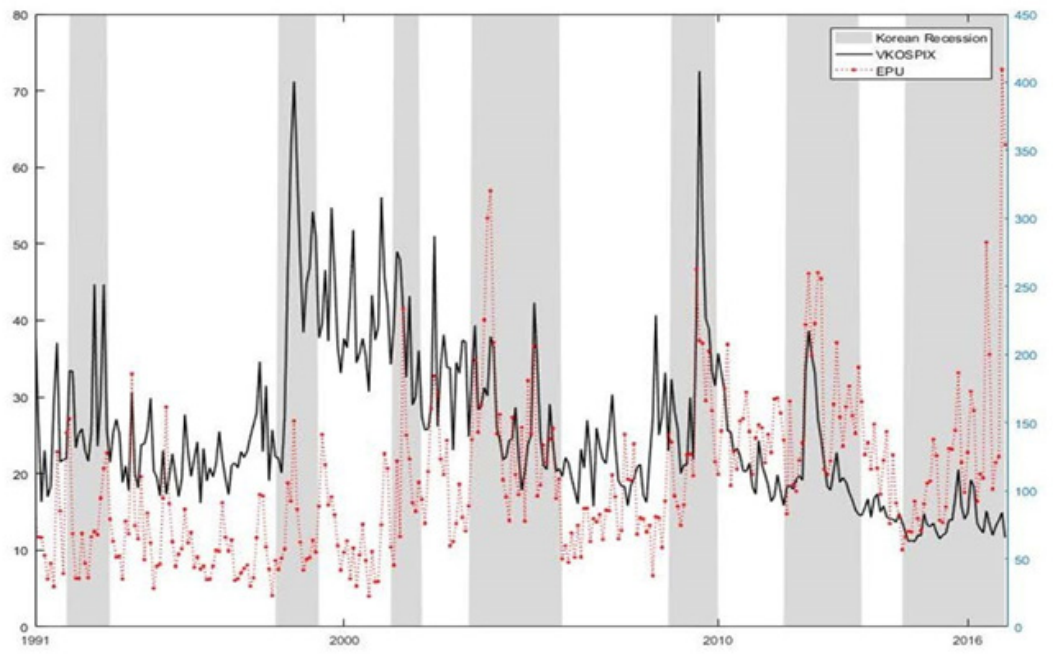

Note: Shaded parts are Korean recessionary periods based on OECD recession indicators.

Figure 2. Probability of Recession

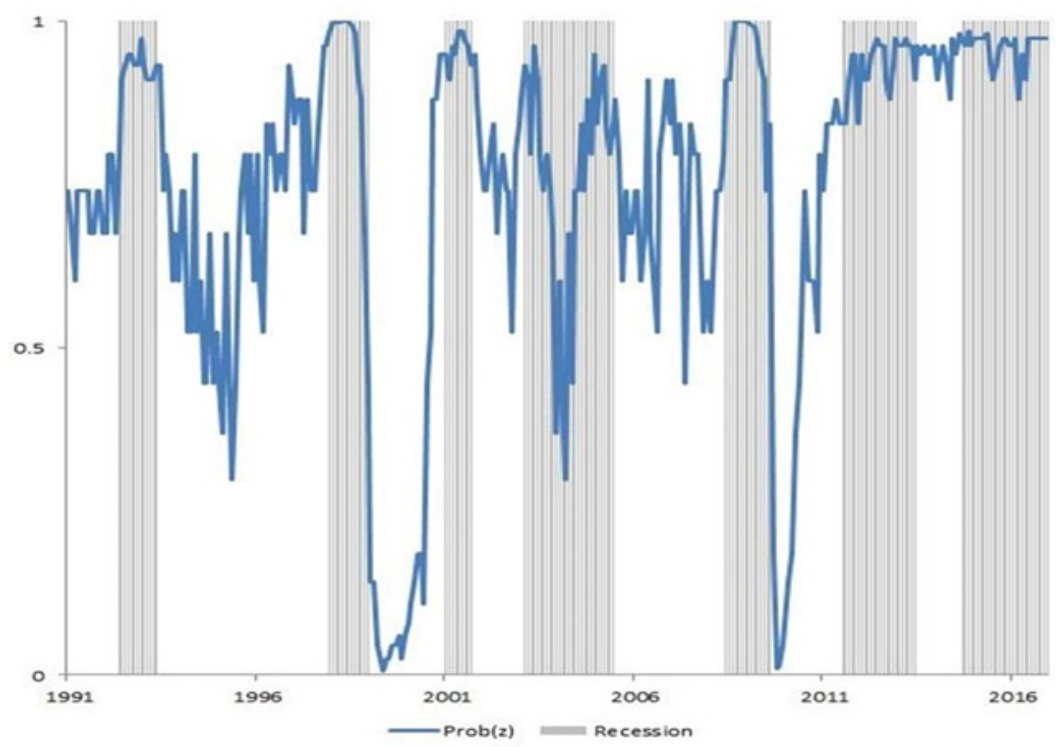

Note: Shaded parts are Korean recessionary periods based on OECD recession indicators. 

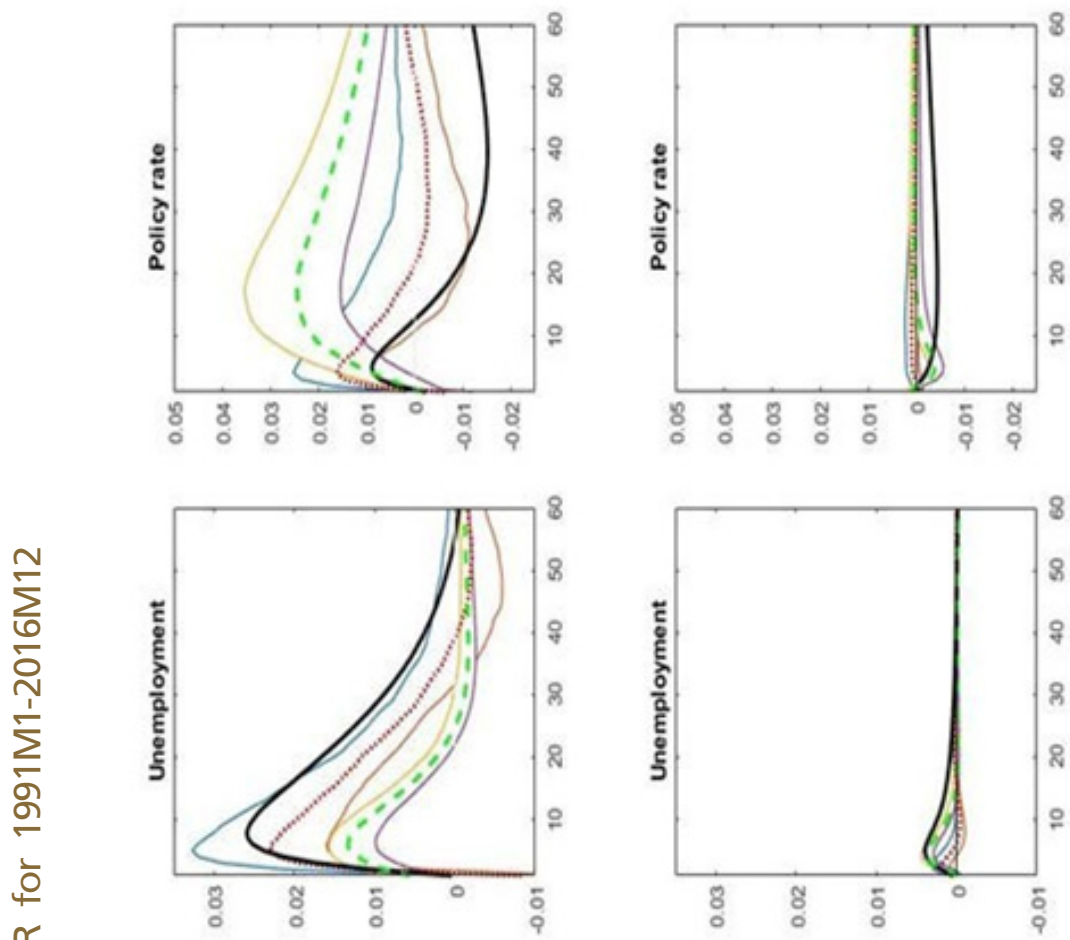

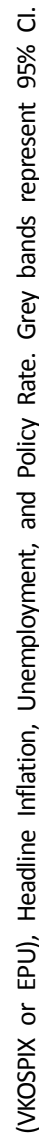
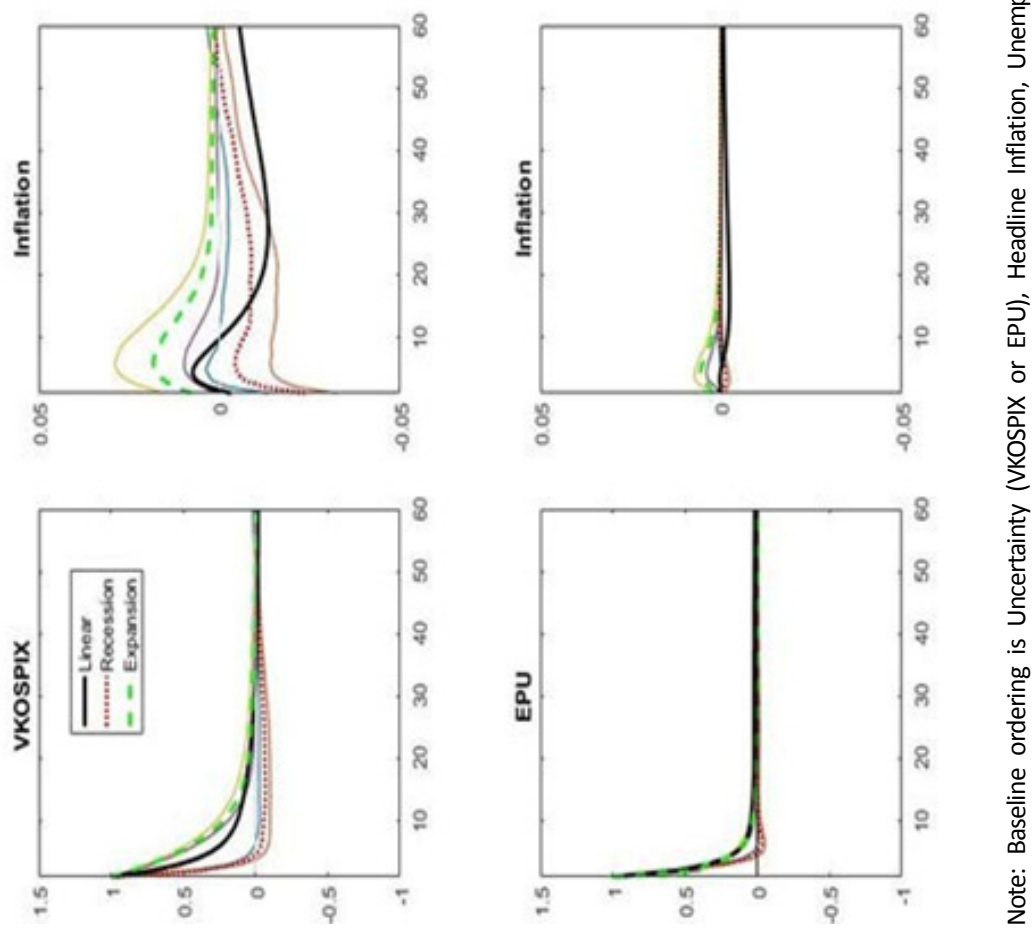

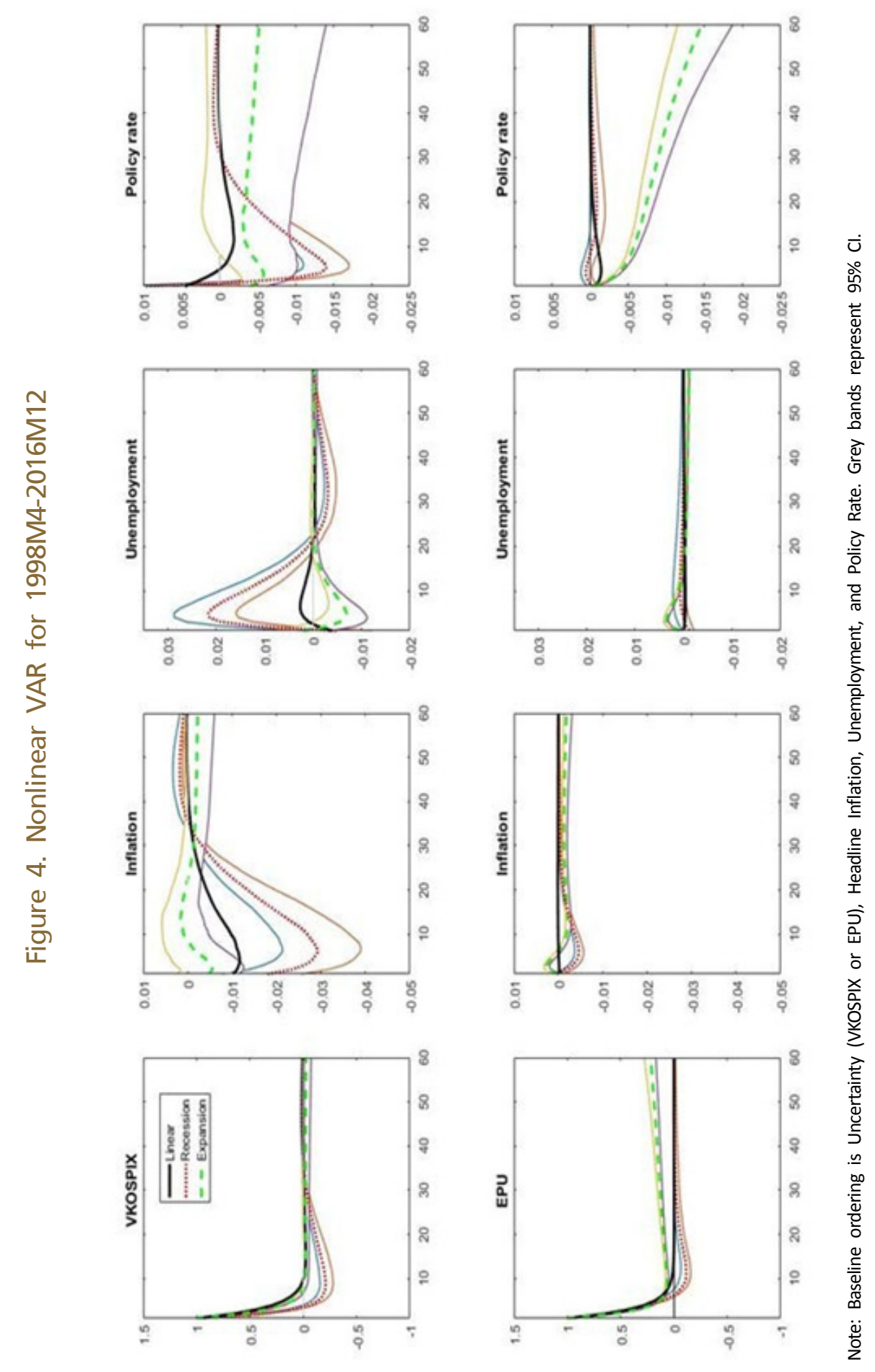


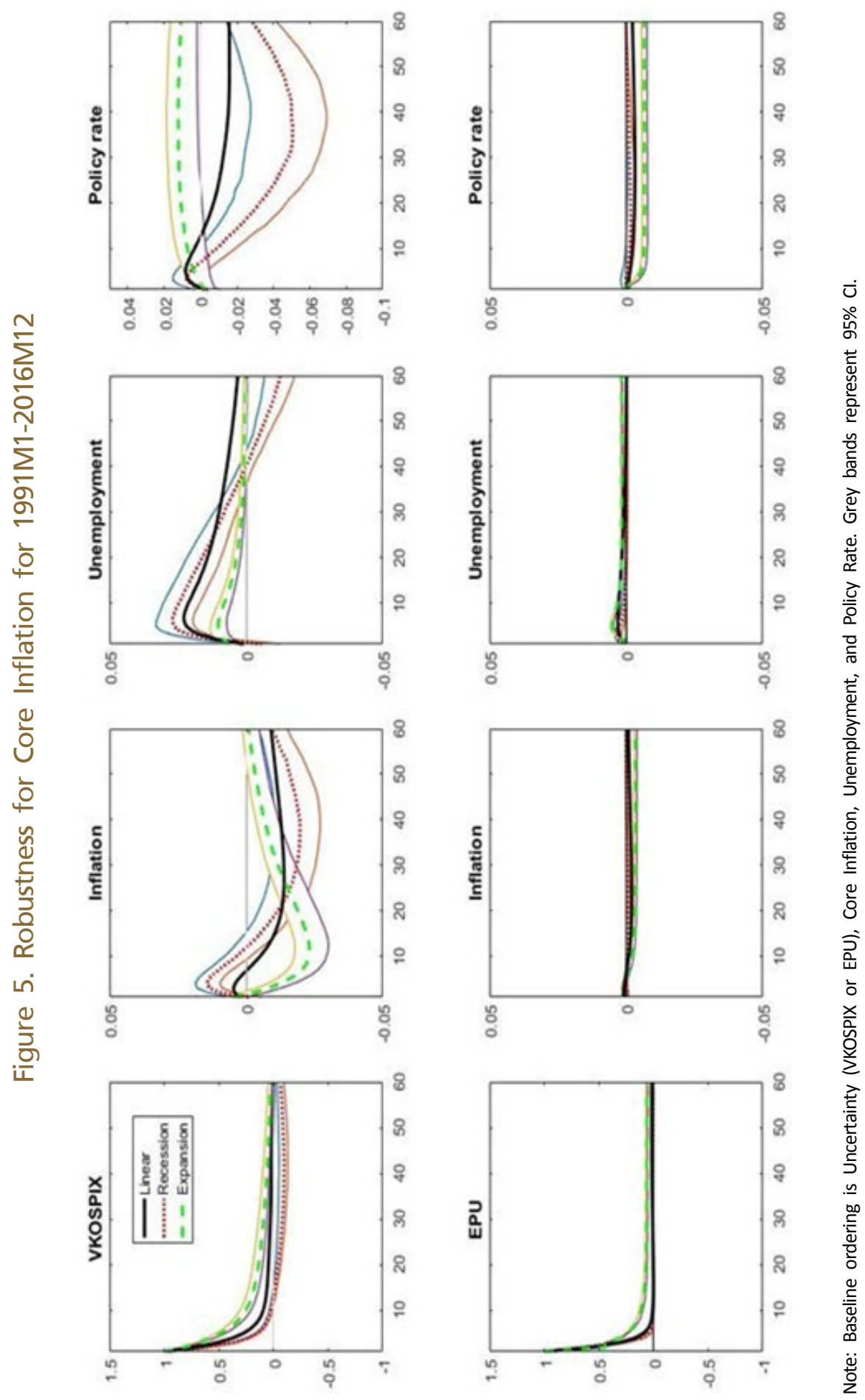




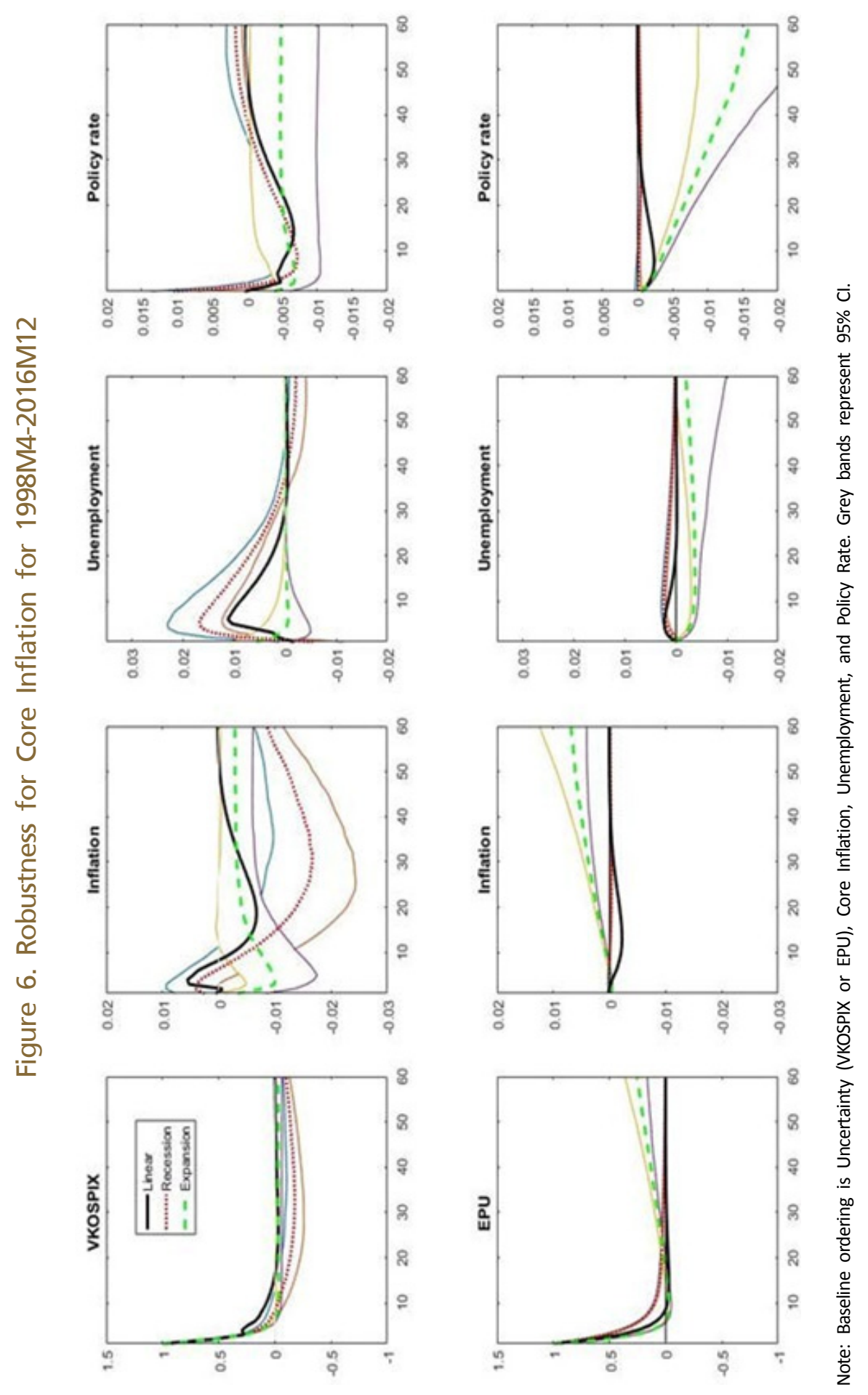




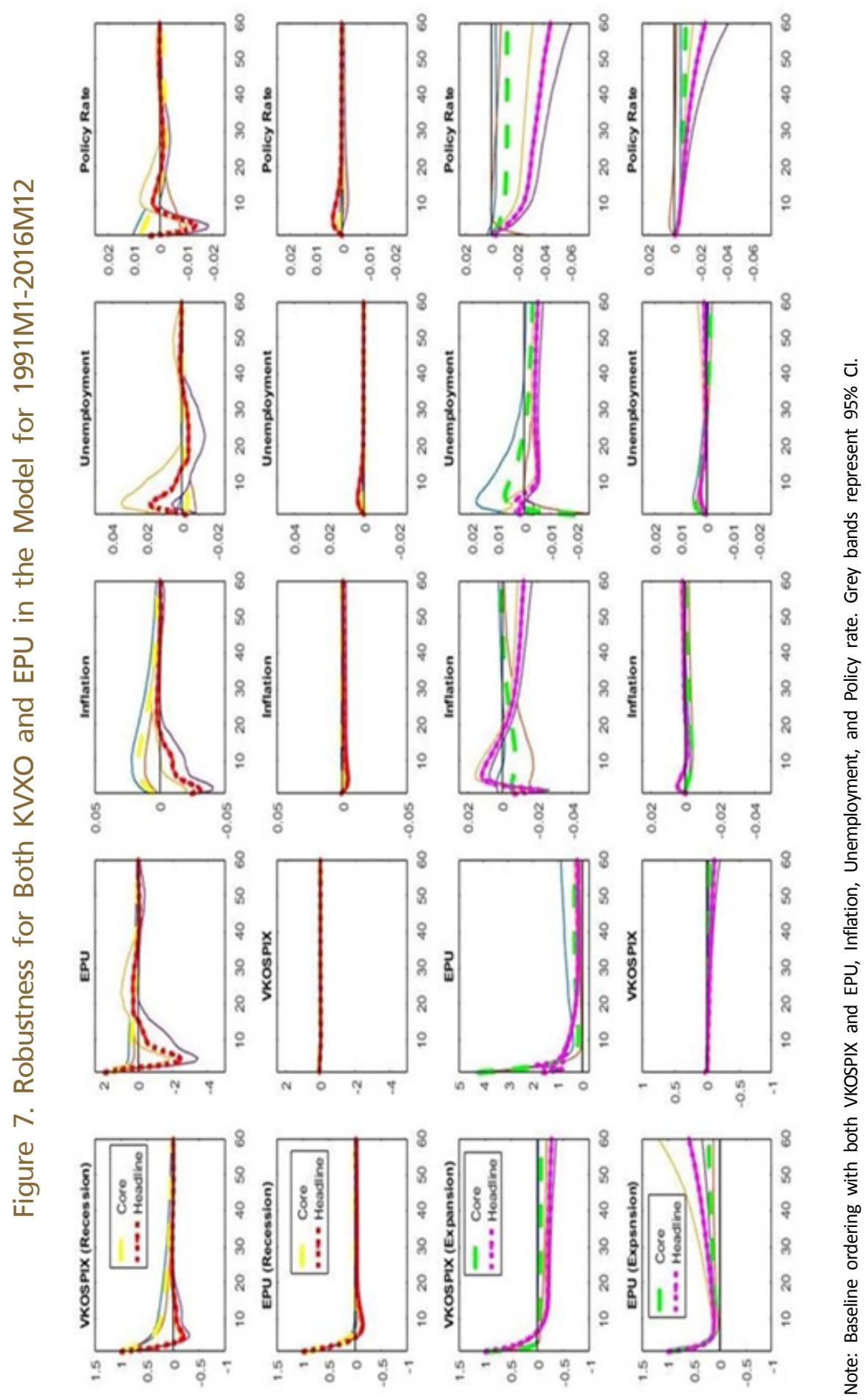




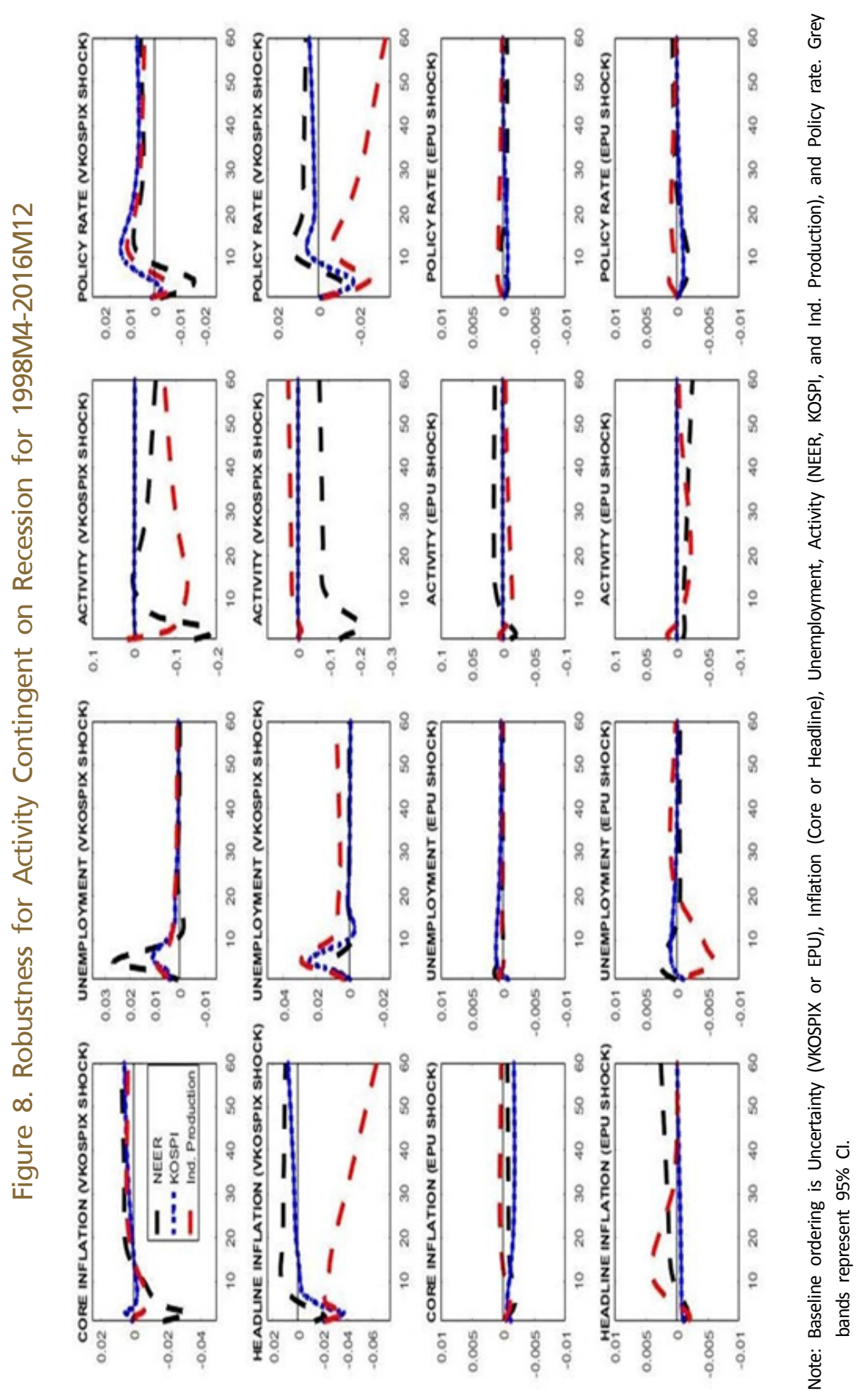



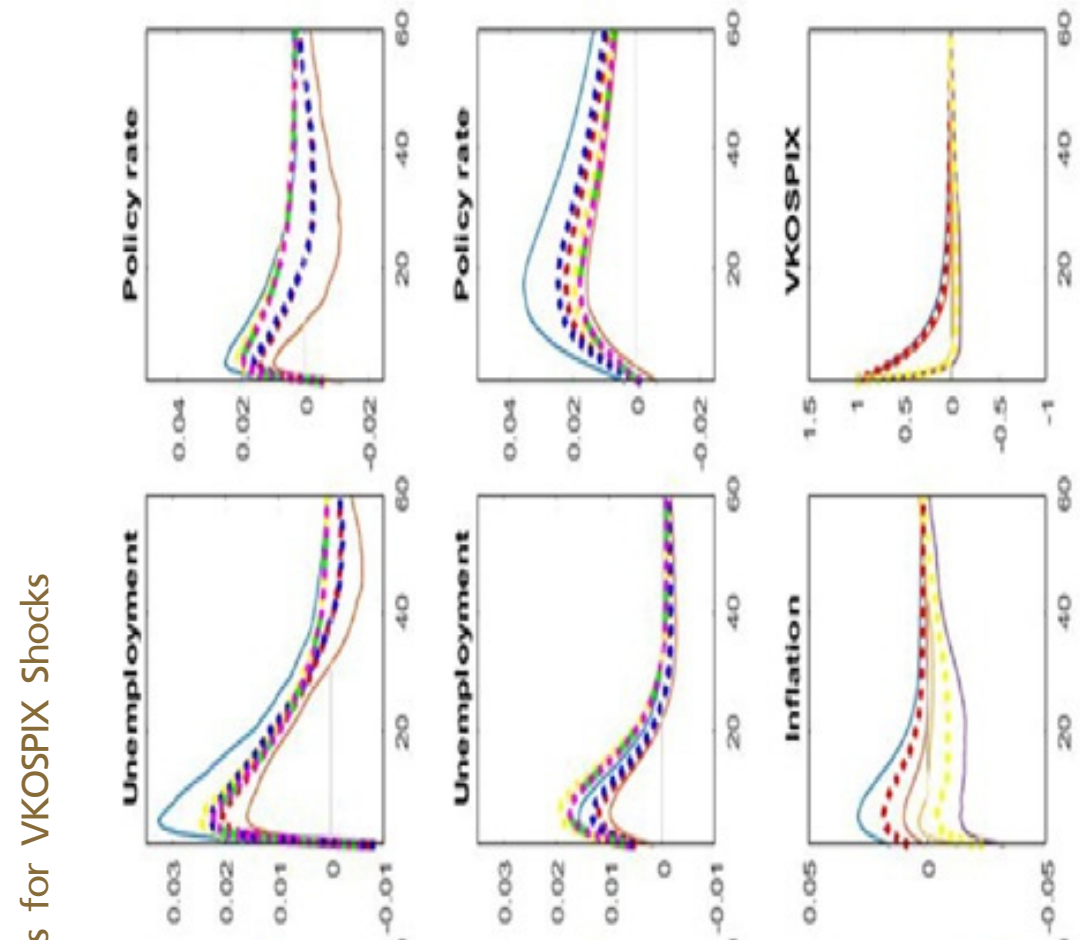

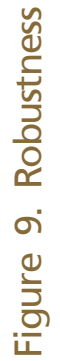
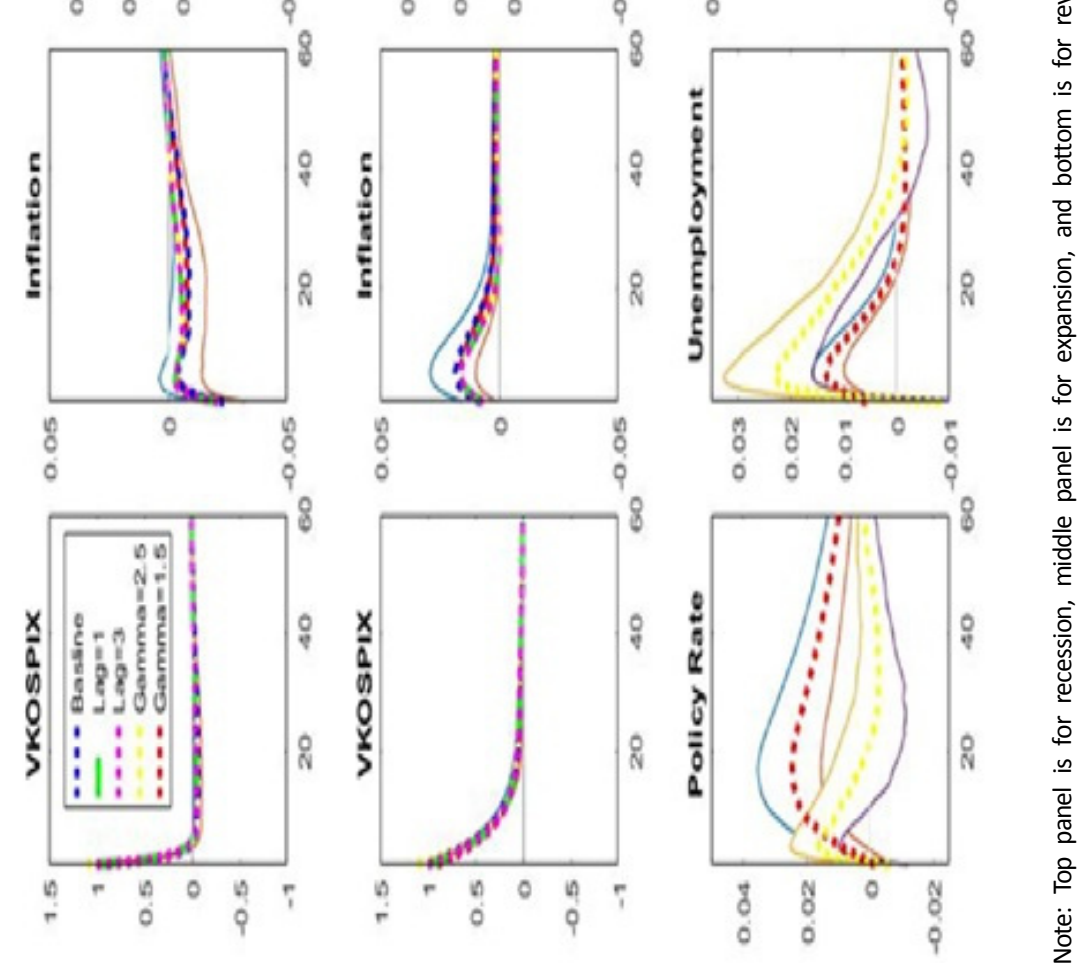

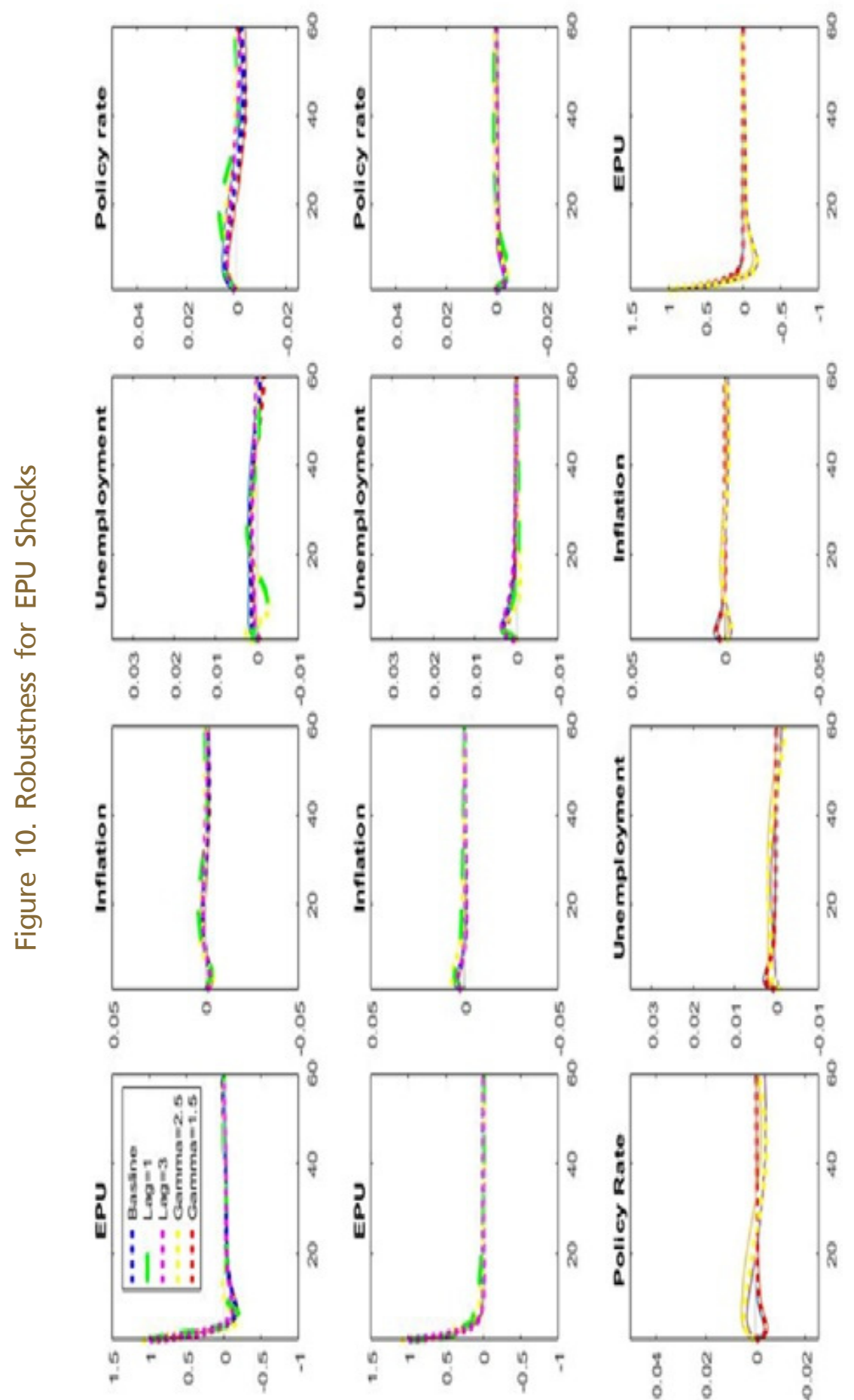

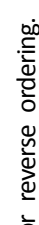

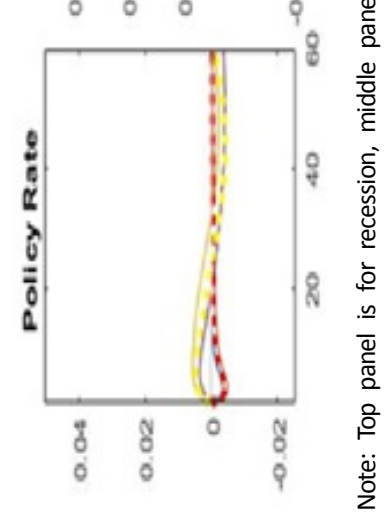


Table 1. Summary Statistics and Data Sources

\begin{tabular}{crrrc} 
Variable & Mean & Min & Max & Source \\
VKOSPIX & 25.78 & 11.13 & 72.56 & DataStream/Korean Exchange \\
EPU & 102.1 & 22.5 & 320.44 & www.policyuncertainty.com \\
Policy Rate & 6.43 & 1.22 & 25.34 & DataStream \\
Core Inflation & 0.28 & -0.29 & 2.11 & DataStream \\
Headline Inflation & 0.3 & -0.6 & 2.54 & DataStream \\
REER & 108.59 & 68.36 & 128.35 & FRED Database \\
KOSPI & 0.005 & -0.27 & 0.48 & DataStream \\
IP & 0.52 & -10.56 & 7.3 & FRED Database \\
& Correlation & Mean & Mean \\
VKOSPIX & 1 & & (Recession) & (Expansion) \\
EPU & 0.05 & 1 & 127.85 & 20.12 \\
\hline
\end{tabular}

Note: All variables are monthly and span time period 1991M1-2016M12.

Table 2. Forecast Error Variance Decomposition: 24 Month-ahead Forecast Error Variance

\begin{tabular}{cccc}
$\begin{array}{c}\text { Shock/Variable } \\
\begin{array}{c}\text { 1991M1 - 2016M12 } \\
\text { VKOSPIX Shock }\end{array}\end{array}$ & Inflation & Policy Rate \\
\hline Recession & 0.13 & 0.11 & 0.10 \\
Expansion & 0.22 & 0.32 & 0.16 \\
\hline EPU Shock & & & \\
Recession & 0.01 & 0.01 & 0.01 \\
Recession & 0.09 & 0.19 & 0.03 \\
\hline 1998M4 - 2016M12 & & & \\
VKOSPIX Shock & 0.18 & 0.08 & 0.14 \\
\hline Recession & 0.08 & 0.05 & 0.26 \\
Expansion & & & 0.01 \\
\hline EPU Shock & 0.02 & 0.01 & 0.37 \\
Recession & 0.01 & 0.01 & \\
Expansion & & & \\
\hline
\end{tabular}




\section{BOK Working Paper No. 2018-12}

\section{References}

Arellano, C., Y. Bai, and P. J. Kehoe (2012), "Financial Markets and Fluctuations in Volatility," Staff Report, No. 466, Federal Reserve Bank of Minneapolis.

Auerbach, A. J. and Gorodnichenko, Y. (2012), "Measuring the Output Responses to Fiscal Policy," American Economic Journal: Economic Policy, Vol. 4(2), pp. 1-27.

Bacchetta, P. and E. Van Wincoop (2013), "Sudden Spikes in Global Risk," Journal of International Economics, Vol. 89(2), pp. 511-521.

Baker, S., Bloom, N., and Davis, S. J. (2016), "Measuring Economic Policy Uncertainty," Quarterly Journal of Economics, Vol. 131(4), pp. 1539-1636.

Basu, S. and B. Bundick (2012), "Uncertainty Shocks in a Model of Effective Demand," http://fmwww.bc.edu/ec-p/wp774.pdf.

Bekaert, G., Hoerova, M., and Duca, M. L. (2013), "Risk, Uncertainty and Monetary Policy," Journal of Monetary Economics, Vol. 60(7), pp. 771-788.

Bloom, N. (2009), "The Impact of Uncertainty Shocks," Econometrica, Vol. $77(3)$, pp. 623-685.

Bloom, N., M. Floetotto, N. Jaimovich, I. Saporta-Eksten, and S. Terry (2012), “Really Uncertain Business Cycles,” NBER Working Paper, No. 18245.

Bodenstein, M., C. J. Erceg, and L. Guerrieri (2008), "Optimal Monetary Policy with Distinct Core and Headline Inflation Rates," Journal of Monetary Economics, Vol. 55, pp. S18-S33.

Born, B. and J. Pfeifer (2014), "Policy Risk and the Business Cycle," Journal of Monetary Economics, Vol. 68, pp. 68-85. 
Caggiano, G., Castelnuovo, E,. and Figueres, J. M. (2017), "Economic Policy Uncertainty and Unemployment in the United States: A Nonlinear Approach," Economics Letters, Vol. 151, pp. 31-34.

Caggiano, G., Castelnuovo, E., and Groshenny, N. (2014), "Uncertainty Shocks and Unemployment Dynamics in Us Recessions," Journal of Monetary Economics, Vol. 67, pp. 78-92.

Caldara, D., Fuentes-Albero, C., Gilchrist, S., and Zakrajšek, E. (2016), "The Macroeconomic Impact of Financial and Uncertainty Shocks," European Economic Review, Vol. 88, pp. 185-207.

Carriere-Swallow, Y. and L. F. Céspedes (2013), "The Impact of Uncertainty Shocks in Emerging Economies," Journal of International Economics, Vol. 90(2), pp. 316-325.

Chernozhukov, V. and Hong, H. (2003), "An MCMC Approach to Classical Estimation, Journal of Econometrics, Vol. 115(2), pp. 293-346.

Choi, S. and Shim, M. (2016), "Financial vs. Policy Uncertainty in Emerging Economies: Evidence from Korea and the BRICs," Open Economies Reviews, forthcoming.

Christiano, L. J., R. Motto, and M. Rostagno (2014), "Risk Shocks," American Economic Review, Vol. 104, pp. 27-65.

Fajgelbaum, P., E. Schaal, and M. Taschereau-Dumouchel (2014), "Uncertainty Traps," NBER Working Paper, No. 19973.

Fernández-Villaverde, J., J. F. R.-R. Pablo Guerrón-Quintana, and M. Uribe (2011), "Risk Matters: The Real Effects of Volatility Shocks," American Economic Review, Vol. 6(101), pp. 2530-61.

Gertler, M, S. Gilchrist, and F. M. Nataluccim (2007), "External Constraints on Monetary Policy and the Financial Accelerator, Journal of Money, Credit and Banking, Vol. 39, pp. 295-330. 
Gilchrist, S., J. W. Sim, and E. Zakrajsek (2014), "Uncertainty, Financial Frictions, and Investment Dynamics," NBER Working Paper, No. 20038.

Granger, C. and Teräsvirta, T. (1993), "Modelling Nonlinear Economic Relationships," Oxford University Press, Oxford.

Hoffmaister, Alexander (1999), "Inflation Targeting in Korea: An Empirical Exploration," IMF Working Paper, No. WP/99/7, Washington, D.C.

Koop, G. and Potter, S. M. (1999), "Dynamic Asymmetries in US Unemployment, Journal of Business \& Economic Statistics, Vol. 17(3), pp. 298-312.

Leduc, S. and Z. Liu (2012), "Uncertainty Shocks are Aggregate Demand Shocks," Federal Reserve Bank of San Francisco, Working Paper 2012-10.

Ludvigson, S. C., S. Ma, and S. Ng (2015), "Uncertainty and Business Cycles: Exogenous Impulse or Endogenous Response?" NBER Working Paper, No. 21803.

Morley, J. and Piger, J. (2012), "The Asymmetric Business Cycle," Review of Economics and Statistics, Vol. 94(1), pp. 208-221.

Rey, H. (2016), "International Channels of Transmission of Monetary Policy and the Mundellian Trilemma," NBER Working Paper, No. 21852.

Shin, Zhang, Zhong, and Lee (2018), "Measuring International Uncertainty: The Case of Korea," Economics Letters, forthcoming.

Teräsvirta, T. (1994), "Specification, Estimation, and Evaluation of Smooth Transition Autoregressive Models," Journal of the American Statistical Association, Vol. 89(425), pp. 208-218.

Teräsvirta, T. and Yang, Y. (2014), "Linearity and Misspecification Tests for Vector Smooth Transition Regression Models," CREATES Research 
Papers 2014-04, School of Economics and Management, University of Aarhus.

Van Dijk, D., Teräsvirta, T., and Franses, P. H. (2002), "Smooth Transition Autoregressive Models. A Survey of Recent Developments," Econometric Review, Vol. 21(1), pp. 1-47.

Van Nieuwerburgh, S. and L. L. Veldkamp (2006), "Learning Asymmetries in Real Business Cycles," Journal of Monetary Economics, Vol. 53, pp. 753-772. 


\section{$<$ Abstract in Korean $>$}

\section{불확실성 충격의 경기국면별 파급효과}

\section{Kevin Larcher*, 김재범**, 김영주 ${ }^{* *}$}

본고는 경제정책 및 금융시장 불확실성 충격이 우리나라 거시경제변수에 미 치는 영향을 분석한다. 불확실성 충격의 영향이 경기 상승 및 하강 국면에 따라 다를 수 있음을 감안하여 경기국면에 따른 파급효과의 비대칭성을 분석할 수 있 는 평활전이 벡터자기회귀모형을 이용하였다. 분석결과 불확실성 충격은 실업 률 상승 등 실물경제에 부정적 영향을 미쳤으며, 그 영향이 경기상승 국면 보다 경기 하강 국면에 더 큰 것으로 나타났다. 두 불확실성 충격 중 금융시장의 불확 실성 확대가 경제정책 불확실성에 비해 우리 경제에 미치는 영향이 전반적으로 큰 것으로 분석되었다. 한편 물가목표제 도입 이후 불확실성의 부정적 영향이 다소 완화된 것으로 나타났다.

핵심 주제어: 불확실성, 평활전이 벡터자기회귀모형, 경기국면별 비대칭성

JEL Classification: C32, E32, E52

* Oklahoma 주립대학교 경제학부(E-mail: larcher@okstate.edu)

** Oklahoma 주립대학교 경제학부 교수(전화: +1-405-744-7359, E-mail: jb.kim@okstate.edu)

*** 한국은행 경제연구원 거시경제연구실 연구위원(전화: 02-759-5475, E-mail: econoky@bok.or.kr) 


\section{$\mathrm{BOK}$ 경제연구 발간목록}

한국은행 경제연구원에서는 Working Paper인 『BOK 경제연구』를 수시로 발간하고 있습니다. 『BOK 경제연구』는 주요 경제 현상 및 정책 효과에 대한 직관적 설명 뿐 아니라 깊이 있는 이론 또는 실증 분석을 제공함으로써 엄밀한 논증에 초점을 두는 학술논문 형태의 연구이며 한국은행 직원 및 한국은행 연구용역사업의 연구 결과물이 수록되고 있습니다.

${ }^{\circledR B O K}$ 경제연구』 는 한국은행 경제연구원 홈페이지(http://imer.bok.or.kr)에서 다운로드하여 보실 수 있습니다.

제2015-1글로벌 금융위기 이후 주요국 통화정책 운영체계의 변화

2 미국 장기시장금리 변동이 우리나라 금리기간구조에 미치는 영향 분석 및 정책적 시사점

3 직간접 무역연계성을 통한 해외충격의 우리나라 수출입 파급효과 분석

4 통화정책 효과의 지역적 차이

5 수입중간재의 비용효과를 고려한 환율변동과 수출가격 간의 관계

6 중앙은행의 정책금리 발표가 주식시장 유동성에 미치는 영향

7 은행 건전성지표의 변동요인과 거시건전성 규제의 영향

8 Price Discovery and Foreign Participation in The Republic of Korea's Government Bond Futures and Cash Markets

9 규제가 노동생산성에 미치는 영향: 한국의 산업패널 자료를 이용한 실증분석

10 인구 고령화와 정년연장 연구 (세대 간 중첩모형(OLG)을 이용한 정량 분석)

11 예측조합 및 밀도함수에 의한 소비자물가 상승률 전망

인플레이션 동학과 통화정책

Failure Risk and the Cross-Section of Hedge Fund Returns
김병기·김인수

강규호·오형석

최문정·김근영

김기호

김경민

이지은

강종구

Jaehun Choi - Hosung Lim • Rogelio Jr. Mercado •

Cyn-Young Park

이동렬·최종일·이종한

홍재화 - 강태수

김현학

우준명

Jung-Min Kim

Hyunju Kang • Bok-Keun $\mathrm{Yu}$. Jongmin $\mathrm{Yu}$ 


\begin{tabular}{|c|c|c|}
\hline 제2015-15 & $\begin{array}{l}\text { Foreign Ownership, Legal System } \\
\text { and Stock Market Liquidity }\end{array}$ & $\begin{array}{l}\text { Jieun Lee } \cdot \\
\text { Kee H. Chung }\end{array}$ \\
\hline 16 & $\begin{array}{l}\text { 바젤피 은행 경기대응완충자본 규제의 } \\
\text { 기준지표에 대한 연구 }\end{array}$ & 서현덕·이정연 \\
\hline 17 & 우리나라 대출 수요와 공급의 변동요인 분석 & 강종구 · 임호성 \\
\hline 18 & 북한 인구구조의 변화 추이와 시사점 & 최지영 \\
\hline 19 & $\begin{array}{l}\text { Entry of Non-financial Firms and Competition } \\
\text { in the Retail Payments Market }\end{array}$ & Jooyong Jun \\
\hline 20 & $\begin{array}{l}\text { Monetary Policy Regime Change } \\
\text { and Regional Inflation Dynamics: } \\
\text { Looking through the Lens of } \\
\text { Sector-Level Data for Korea }\end{array}$ & $\begin{array}{l}\text { Chi-Young Choi } \\
\text { Joo Yong Lee } \\
\text { Roisin O'Sullivan }\end{array}$ \\
\hline 21 & $\begin{array}{l}\text { Costs of Foreign Capital Flows } \\
\text { in Emerging Market Economies: } \\
\text { Unexpected Economic Growth } \\
\text { and Increased Financial Market Volatility }\end{array}$ & $\begin{array}{l}\text { Kyoungsoo Yoon } \\
\text { Jayoung Kim }\end{array}$ \\
\hline 22 & $\begin{array}{l}\text { 글로벌 금리 정상화와 통화정책 과제: } \\
\text { 2015년 한국은행 국제컨퍼런스 결과보고서 }\end{array}$ & 한국은행 경제연구원 \\
\hline 23 & $\begin{array}{l}\text { The Effects of Global Liquidity } \\
\text { on Global Imbalances }\end{array}$ & $\begin{array}{l}\text { Marie-Louise DJIGBENOU-KRE } \\
\text { Hail Park }\end{array}$ \\
\hline 24 & 실물경기를 고려한 내재 유동성 측정 & 우준명·이지은 \\
\hline 25 & Deflation and Monetary Policy & Barry Eichengreen \\
\hline 26 & $\begin{array}{l}\text { Macroeconomic Shocks } \\
\text { and Dynamics of Labor Markets in Korea }\end{array}$ & $\begin{array}{l}\text { Tae Bong Kim } \cdot \\
\text { Hangyu Lee }\end{array}$ \\
\hline 27 & $\begin{array}{l}\text { Reference Rates and Monetary Policy } \\
\text { Effectiveness in Korea }\end{array}$ & $\begin{array}{l}\text { Heung Soon Jung } \\
\text { Dong Jin Lee } \\
\text { Tae Hyo Gwon } \\
\text { Se Jin Yun }\end{array}$ \\
\hline 28 & Energy Efficiency and Firm Growth & $\begin{array}{l}\text { Bongseok Choi } \\
\text { Wooyoung Park } \\
\text { Bok-Keun Yu }\end{array}$ \\
\hline 29 & $\begin{array}{l}\text { An Analysis of Trade Patterns } \\
\text { in East Asia and the Effects of } \\
\text { the Real Exchange Rate Movements }\end{array}$ & $\begin{array}{l}\text { Moon Jung Choi } \\
\text { Geun-Young Kim } \\
\text { Joo Yong Lee }\end{array}$ \\
\hline 30 & $\begin{array}{l}\text { Forecasting Financial Stress Indices in } \\
\text { Korea: A Factor Model Approach }\end{array}$ & $\begin{array}{l}\text { Hyeongwoo Kim } \\
\text { Hyun Hak Kim } \\
\text { Wen Shi }\end{array}$ \\
\hline
\end{tabular}




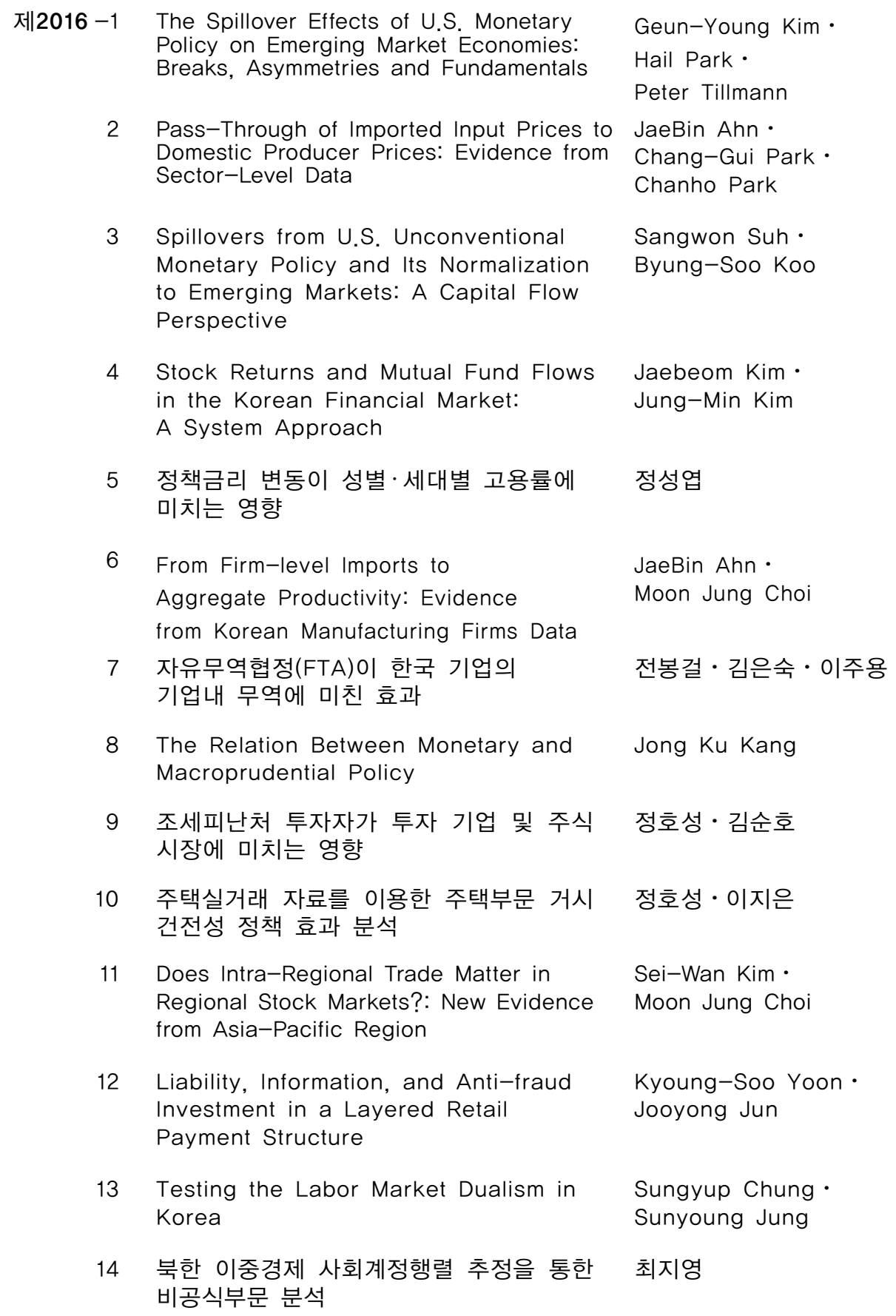

2 Pass-Through of Imported Input Prices to Domestic Producer Prices: Evidence from Sector-Level Data

Geun-Young Kim •

Hail Park •

Peter Tillmann

JaeBin Ahn .

Chang-Gui Park •

Chanho Park

3 Spillovers from U.S. Unconventional Monetary Policy and Its Normalization to Emerging Markets: A Capital Flow Perspective

Sangwon Suh $\cdot$ Byung-Soo Koo

4 Stock Returns and Mutual Fund Flows in the Korean Financial Market:

A System Approach

5 정책금리 변동이 성별·세대별 고용률에 미치는 영향

6 From Firm-level Imports to Aggregate Productivity: Evidence from Korean Manufacturing Firms Data

7 자유무역협정(FTA)이 한국 기업의 기업내 무역에 미친 효과

8 The Relation Between Monetary and Macroprudential Policy

Jaebeom Kim . Jung-Min Kim

정성엽

JaeBin Ahn .

Moon Jung Choi

전봉걸 · 김은숙 · 이주용

Jong Ku Kang

9 조세피난처 투자자가 투자 기업 및 주식 시장에 미치는 영향

10 주택실거래 자료를 이용한 주택부문 거시 건전성 정책 효과 분석

11 Does Intra-Regional Trade Matter in Regional Stock Markets?: New Evidence from Asia-Pacific Region

12 Liability, Information, and Anti-fraud Investment in a Layered Retail Payment Structure

13 Testing the Labor Market Dualism in Korea

정호성·김순호

정호성·이지은

Sei-Wan Kim • Moon Jung Choi

Kyoung-Soo Yoon $\cdot$ Jooyong Jun

Sungyup Chung • Sunyoung Jung

14 북한 이중경제 사회계정행렬 추정을 통한 최지영 비공식부문 분석 


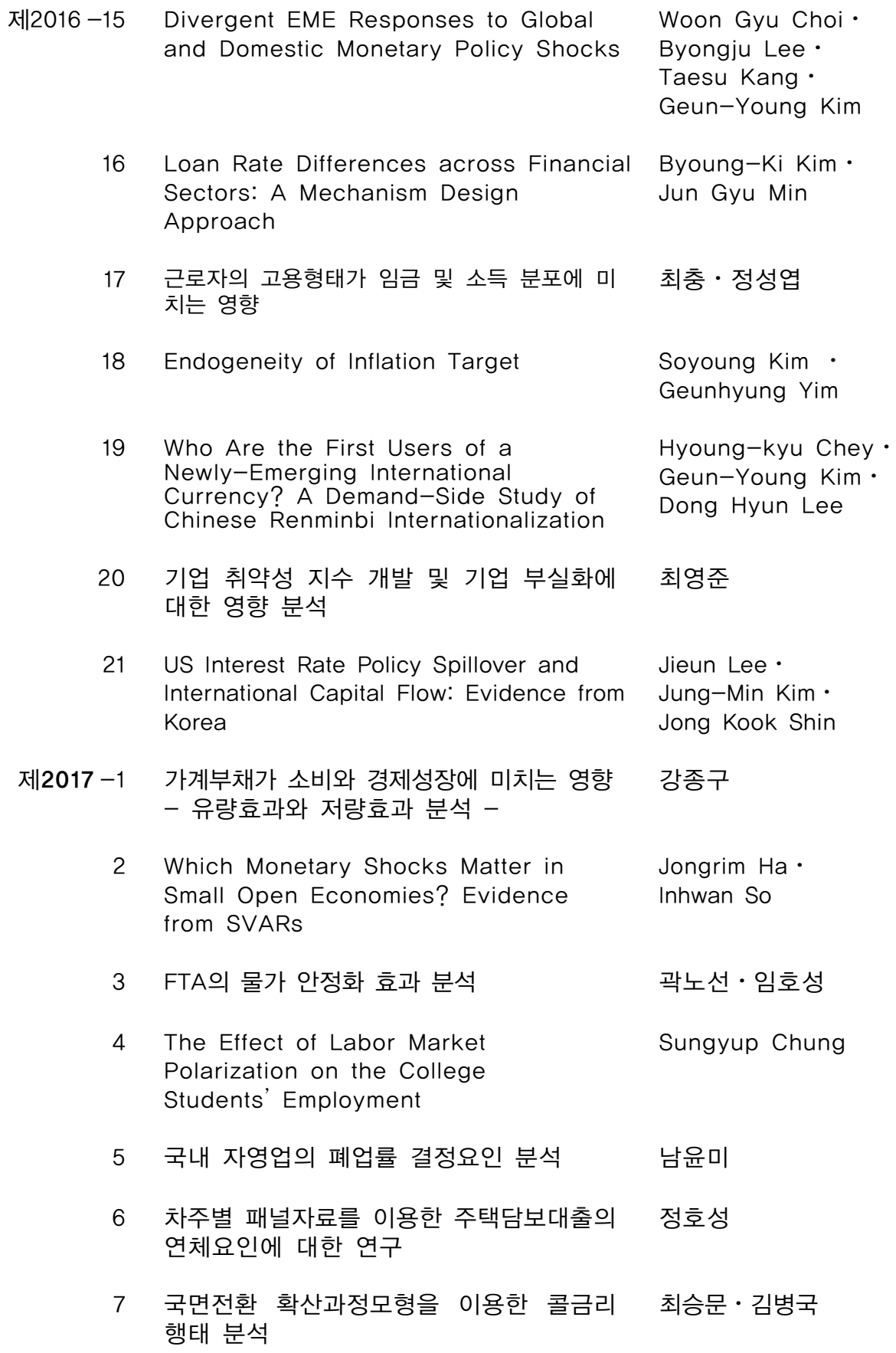




\begin{tabular}{|c|c|c|}
\hline 제2017 -8 & $\begin{array}{l}\text { Behavioral Aspects of Household } \\
\text { Portfolio Choice: Effects of Loss } \\
\text { Aversion on Life Insurance Uptake } \\
\text { and Savings }\end{array}$ & In Do Hwang \\
\hline 9 & 신용공급 충격이 재화별 소비에 미치는 영향 & 김광환 · 최석기 \\
\hline 10 & 유가가 손익분기인플레이션에 미치는 영향 & 김진용·김준철·임형준 \\
\hline 11 & $\begin{array}{l}\text { 인구구조변화가 인플레이션의 장기 추세에 } \\
\text { 미치는 영향 }\end{array}$ & 강환구 \\
\hline 12 & $\begin{array}{l}\text { 종합적 상환여건을 반영한 과다부채 } \\
\text { 가계의 리스크 요인 분석 }\end{array}$ & 이동진·한진현 \\
\hline 13 & $\begin{array}{l}\text { Crowding out in a Dual Currency Regime? } \\
\text { Digital versus Fiat Currency }\end{array}$ & $\begin{array}{l}\text { KiHoon Hong } \\
\text { Kyounghoon Park } \\
\text { Jongmin Yu }\end{array}$ \\
\hline 14 & $\begin{array}{l}\text { Improving Forecast Accuracy of } \\
\text { Financial Vulnerability: Partial Least } \\
\text { Squares Factor Model Approach }\end{array}$ & $\begin{array}{l}\text { Hyeongwoo Kim. } \\
\text { Kyunghwan Ko }\end{array}$ \\
\hline 15 & $\begin{array}{l}\text { Which Type of Trust Matters?: } \\
\text { Interpersonal vs. Institutional vs. } \\
\text { Political Trust }\end{array}$ & In Do Hwang \\
\hline 16 & 기업특성에 따른 연령별 고용행태 분석 & 이상욱·권철우·남윤미 \\
\hline 17 & $\begin{array}{l}\text { Equity Market Globalization and } \\
\text { Portfolio Rebalancing }\end{array}$ & $\begin{array}{l}\text { Kyungkeun Kim } \\
\text { Dongwon Lee }\end{array}$ \\
\hline 18 & $\begin{array}{l}\text { The Effect of Market Volatility on } \\
\text { Liquidity and Stock Returns in the } \\
\text { Korean Stock Market }\end{array}$ & Jieun Lee $\cdot \mathrm{KeeH}$.Chung \\
\hline 19 & $\begin{array}{l}\text { Using Cheap Talk to Polarize or Unify } \\
\text { a Group of Decision Makers }\end{array}$ & Daeyoung Jeong \\
\hline 20 & $\begin{array}{l}\text { 패스트트랙 기업회생절차가 법정관리 기업의 } \\
\text { 이자보상비율에 미친 영향 }\end{array}$ & 최영준 \\
\hline 21 & 인구고령화가 경제성장에 미치는 영향 & 안병권·김기호·육승환 \\
\hline 22 & $\begin{array}{l}\text { 고령화에 대응한 인구대책: OECD사례를 중심 } \\
\text { 으로 }\end{array}$ & 김진일· 박경훈 \\
\hline
\end{tabular}




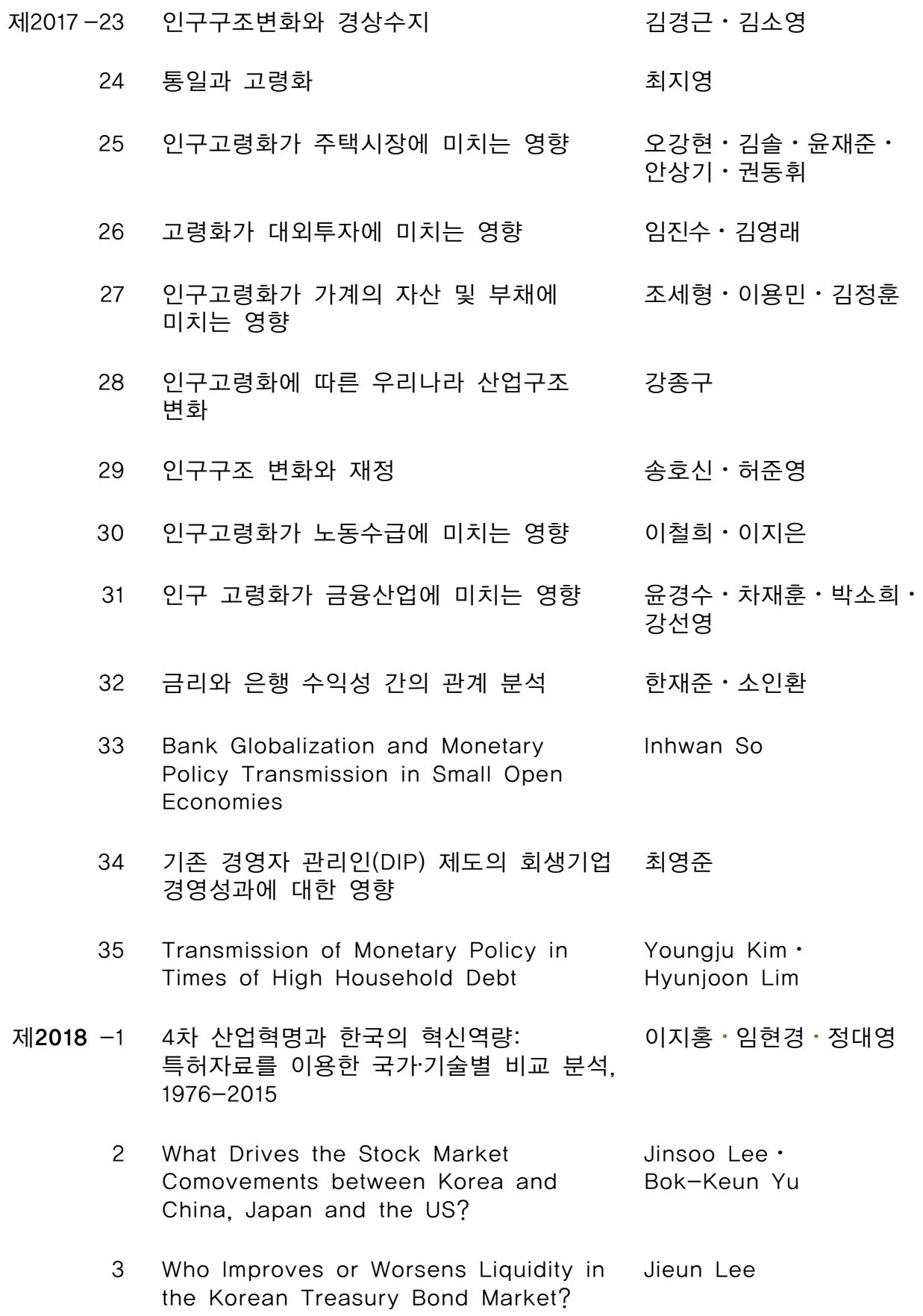

34 기존 경영자 관리인(DIP) 제도의 회생기업 경영성과에 대한 영향

35 Transmission of Monetary Policy in Times of High Household Debt

Youngju Kim • Hyunjoon Lim

제2018 -1 4차 산업혁명과 한국의 혁신역량:

특허자료를 이용한 국가-기술별 비교 분석, 이지홍·임현경·정대영 1976-2015

2 What Drives the Stock Market Comovements between Korea and China, Japan and the US?

3 Who Improves or Worsens Liquidity in Jieun Lee the Korean Treasury Bond Market? 


\begin{tabular}{|c|c|c|}
\hline 제2018 -4 & $\begin{array}{l}\text { Establishment Size and Wage } \\
\text { Inequality: The Roles of Performance } \\
\text { Pay and Rent Sharing }\end{array}$ & Sang-yoon Song \\
\hline 5 & $\begin{array}{l}\text { 가계대출 부도요인 및 금융업권별 } \\
\text { 금융취약성: 자영업 차주를 중심으로 }\end{array}$ & 정호성 \\
\hline 6 & $\begin{array}{l}\text { 직업훈련이 청년취업률 제고에 미치는 } \\
\text { 영향 }\end{array}$ & 최충·김남주 · 최광성 \\
\hline 7 & 재고투자와 경기변동에 대한 동학적 분석 & 서병선·장근호 \\
\hline 8 & $\begin{array}{l}\text { Rare Disasters and Exchange Rates: } \\
\text { An Empirical Investigation of South } \\
\text { Korean Exchange Rates under Tension } \\
\text { between the Two Koreas }\end{array}$ & $\begin{array}{l}\text { Cheolbeom Park } \\
\text { Suyeon Park }\end{array}$ \\
\hline 9 & $\begin{array}{l}\text { 통화정책과 기업 설비투자 } \\
\text { - 자산가격경로와 대차대조표경로 분석 - }\end{array}$ & 박상준 · 육승환 \\
\hline 10 & $\begin{array}{l}\text { Upgrading Product Quality: } \\
\text { The Impact of Tariffs and Standards }\end{array}$ & Jihyun Eum \\
\hline 11 & 북한이탈주민의 신용행태에 관한 연구 & 정승호·민병기·김주원 \\
\hline 12 & $\begin{array}{l}\text { Uncertainty Shocks and Asymmetric } \\
\text { Dynamics in Korea: A Nonlinear } \\
\text { Approach }\end{array}$ & $\begin{array}{l}\text { Kevin Larcher. } \\
\text { Jaebeom Kim } \\
\text { Youngju Kim }\end{array}$ \\
\hline
\end{tabular}

